\title{
Hypothesizing “Reward” Gene Polymorphisms May Predict High Rates of Injury and Addiction in the Workforce: $A$ Nutrient and Electrotherapeutic Based Solution
}

\author{
Kenneth Blum 1-7*, Thomas Simpaatico3, Roger L. Waite², Seth H. Blum², Kristina Dushaj3, \\ Margaret A. Madigan 2,6, Eric R. Braverman 1,3, Marlene Oscar-Bermanm ${ }^{8}$ \\ ${ }^{1}$ Department of Psychiatry and McKnight Brain Institute, University of Florida, College of Medicine, \\ Gainesville, USA \\ ${ }^{2}$ Department of Nutrigenomic Research, RDSolutions, LLC, Del Mar, USA \\ ${ }^{3}$ Department of Neurology, PATH Foundation NY, New York, USA \\ ${ }^{4}$ Dominion Diagnostics, LLC, North Kingstown, USA \\ ${ }^{5}$ Department of Psychiatry, Human Integrated Services Unit University of Vermont Center for Clinical \& \\ Translational Science, College of Medicine, Burlington, USA \\ ${ }^{6}$ Department of Genomics, IGENE, LLC, Austin, USA \\ ${ }^{7}$ Department of Addiction Research \& Therapy, Malibu Beach Recovery Center, Malibu Beach, USA \\ ${ }^{8}$ Departments of Psychiatry, Neurology, and Anatomy \& Neurobiology, Boston University School of Medicine, \\ and Boston VA Healthcare System, Boston, USA \\ Email: ${ }^{*}-$ drd2gene@gmail.com
}

Received 14 July 2014; revised 31 August 2014; accepted 1 September 2014

Copyright @ 2014 by authors and Scientific Research Publishing Inc.

This work is licensed under the Creative Commons Attribution International License (CC BY).

http://creativecommons.org/licenses/by/4.0/

cC) (i) Open Access

\begin{abstract}
We hypothesize that individuals with genetic predisposition to Substance Use Disorder (SUD) may have greater likelihood of experiencing work related accidents. We further hypothesize that high risk populations will carry single or multiple polymorphisms associated with brain reward circuitry and/or brain reward cascade, including: Dopaminergic (i.e. DRD2 receptor genes); Serotonergic (i.e. 5-HTT2 receptor genes); Endorphinergic (i.e. pre-enkephalin genes); Gabergic (i.e. $\mathrm{GABA}_{\mathrm{A}}$ receptor genes); Neurotransmitter Metabolizing genes (i.e. MAO and COMT genes) among others

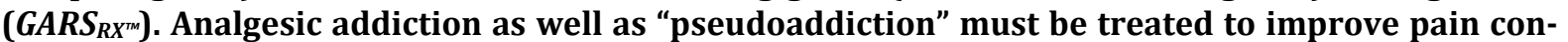
trol and its management. We propose that non-pharmacological alternatives to pain relief, in high
\end{abstract}

${ }^{*}$ Corresponding author.

How to cite this paper: Blum, K., et al. (2014) Hypothesizing "Reward" Gene Polymorphisms May Predict High Rates of Injury and Addiction in the Workforce: A Nutrient and Electrotherapeutic Based Solution. Health, 6, 2261-2285. 
risk, addiction-prone individuals, are Electrotherapeutic Device(s) and Programs. We further propose patented KB220Z, a nutraceutical designed to release dopamine at the nucleus accumbens, will reduce craving behavior, in genetically programmed individuals. By utilizing both alternatives in DNA analyzed injured workers, a reduction in analgesic addiction (genuine or pseudo) leads to improved health and quicker return to work. We also hypothesize that this novel approach will impact costs related to injuries in the workforce. Effective management of chronic pain, especially in high addiction-prone workforce populations, is possible in spite of being particularly elusive. A series of factors encumber pain assessment and management, including analgesia addiction, pharmacogenomic response to pain medications, and genetically inherited factors involving gene polymorphisms. Additional research is required to test these stipulated hypotheses related to genetic proneness to addiction, but also proneness to accidents in the workplace and reduction of craving behavior. Our hypothesis that genotyping coupled with both $\mathrm{KB}^{2} 2 \mathrm{Z}^{\mathrm{TM}}$ and the pharmaceutical-free Electrotherapy, will reduce iatrogenic induced analgesia addiction. This approach will achieve attainable effective pain management and quicker return to work. We propose outcomes such as the Reward Deficiency System Solution ${ }^{\mathrm{TM}}$ may become an adjunct in the war against iatrogenic pain medication addiction.

\section{Keywords}

Injuries, Workforce, Reward Gene Polymorphisms, KB220Z, Electrotherapy Device \& Program, Iatrogenic Analgesic Addiction, Reward Deficiency System Solution

\section{Introduction}

In this paper we have suggested that individuals presenting with work related accidents may have a number of reward gene polymorphisms that lead to a hypodopaminergic trait and as such enhance addictive behaviors. We propose that coupling Genetic Addiction Risk Score (GARSRX) with dopaminergic agonistic modalities (such as KB220Z and an electrotherapeutic anti-pain device) will reduce unwanted accidents and reduce the chance of becoming addicted to opioids in the workplace.

\section{Population Addiction Trends}

In 2009 the United States population consisted of 248 million people older than twelve years of age [1]. A 2009 study reported that of United States persons aged 12 and older, 117 million people had used illicit drugs in their lifetime (47.1\%), 38 million had used illicit drugs in the last year (15.1\%) and 22 million had used illicit drugs in the last 30 days (8.7\%) [1]. In 1999 the estimated resource costs of substance abuse to society was $\$ 172.2$ billion and when accounting for productivity costs accumulated to $\$ 510.8$ billion [2]. Resource costs were comprised of prevention and specialty services (8.9\%), medical treatments (58.8\%), and services and goods related to accidents and criminal services (32.2\%) [2]. Productivity costs were comprised of premature death loss in productivity (41.4\%), substance abuse (SA) illness work productivity loss (37.7\%), crime victim work loss (0.9\%), and incarceration or criminal career work loss (19.9\%) [2]. United States 2003 expenditures on illegal drugs were estimated to range between $\$ 86.3$ billion to $\$ 103.2$ billion, with approximately $\$ 36.3$ billion spent on cocaine, $\$ 10.0$ billion spent on heroin, \$13.2 billion spent on methamphetamine and 35.2 billion spent on marijuana [3]. Moreover, in 2003, an estimated 19.5 million Americans, or $8.2 \%$ of the population aged 12 or older, were current illicit drug users [4]. Furthermore, in 2005 Washington state-level analysis indicated that SA was associated with $7 \%$ of all state-level deaths, 89,000 years of life productivity loss and 29,000 hospital discharges [5]. These staggering figures necessitate the development of pointed and effective treatment and prevention solutions for SA; success in this endeavor would help mitigate the monetary burden associated with SA.

\subsection{Addiction in the Workforce Trends}

The burden of addiction in a well-educated workforce was examined by Matano et al. in a comprehensive study, in which a randomly sampled group of a workforce $(n=504)$, with a $60 \%$ response rate, was surveyed for their 
substance use, including alcohol use as well as legal and illegal drug use [6]. Of responders, 87\% reported alcohol use over the last year, $13 \%$ reported daily alcohol consumption of three or more drinks, and 15\% were binge drinkers [6]. High likelihood for lifelong alcohol dependence occurred in 12\% of responders, and current problem drinking criteria was met by 5\% [6]. 11\% reported illicit drug use in the last year, and most notably, 42\% reported mood-altering prescription drug use (sedatives, marijuana, analgesics, or antidepressants) [6]. Many demographic factors found significant relationships with certain measures of mood-altering drug use and alcohol consumption, including gender, occupation, age, and ethnicity [6]. This survey highlights the high mood-altering substance use in well educated workforces and further stimulates the necessity for early treatment and preventative solutions to address mood-altering drug use in these populations [6].

\subsection{Injury in the Workforce Trends}

Every year, millions of people incur occupational injuries and illnesses. In the United States and Canada, injured workers face a greater chance of lost earnings compared to other countries. The largest declines are documented in the United States, Canada and the UK. One major reason for the differences between these three countries and others involve stronger employment protection laws in countries like Germany and France [7].

The health, well-being and productivity of workers and employers in today's society are becoming increasingly important. The social, emotional and economic costs of injury and illness are such that governments throughout the world are attempting to implement policies and practices to contain costs [8].

\subsubsection{USA}

Workers' compensation for workplace injuries is costly to all involved parties yet can be mitigated through prevention and earlier return to work. Melhorn, in a 2001 study entitled "Occupational orthopaedics in this millennium” said these preventative practices would be the future for musculoskeletal pain treatment in occupational medicine [9]. Staggering rates of patients receive workers' compensation, comprising 90\% of independent medical examiner practice patients, $65 \%$ of hand surgeon practice patients, and $20 \%$ of general orthopedist practice patients [9]. Moreover, of the United States workforce, it has been predicted that more than half have experienced an occupational illness or injury [9]. Khan et al., in a 2004 macroeconomic investigation of sickness and disability spending, discovered that average occupation injury benefit was 74.1 US dollars per capita, with the highest spending occurring for disability pension, at an average of 324.5 US dollars [10].

\subsubsection{Canada}

Investigations of workplace injuries and preventative measures have been undertaken in the Canadian healthcare sectors, in which workers' compensation data and safety and occupational health trends have been investigated [11]. Through collection of time loss claims data from the Association of Workers' Compensation Boards of Canada, between the period of 1992-2002, and with use of Statistics Canada Labor Force data, injury data was analyzed and preventative measures collated [1]. The results of this study determined that there was a reduction in national time loss injury rates from 4.3 to 3.7 injuries per 100 person-years since 1998 [11]. Moreover, the majority of time loss claims resulted from musculoskeletal injuries, with infrequent occurrences resulting from stress-related claims, infectious diseases or injuries caused by needle sticks, all of these injuries are of great workplace concern [11].

\subsection{Brain Reward Circuitry}

\section{Dopaminergic Genes and Addictive Behavior}

The dopaminergic system and dopamine D2 receptor are important players in brain reward circuitry, having been implicated as mechanisms of reward [12]. More specifically, the neurotransmitter mesolimbic brain region net effect induces "reward” when neuronal dopamine (DA) release interacts with a dopamine D2 receptor at the nucleus accumbens (NAc) [12]-[23]. The "reward cascade” [24] in this process involves serotonin release, stimulating hypothalamic enkephalin release, inhibiting substania nigra GABA, thereby regulating the amount of DA release at the NAc or “reward site” [25]-[29] (Figure 1(a), Figure 1(b) and Figure 2).

Under normal conditions, our normal drives are maintained by DA in the NAc [30]-[32]. Known as the “pleasure molecule” [12] [33]-[38] and "anti-stress molecule” [39]-[41], dopamine, when released into the synapse, 


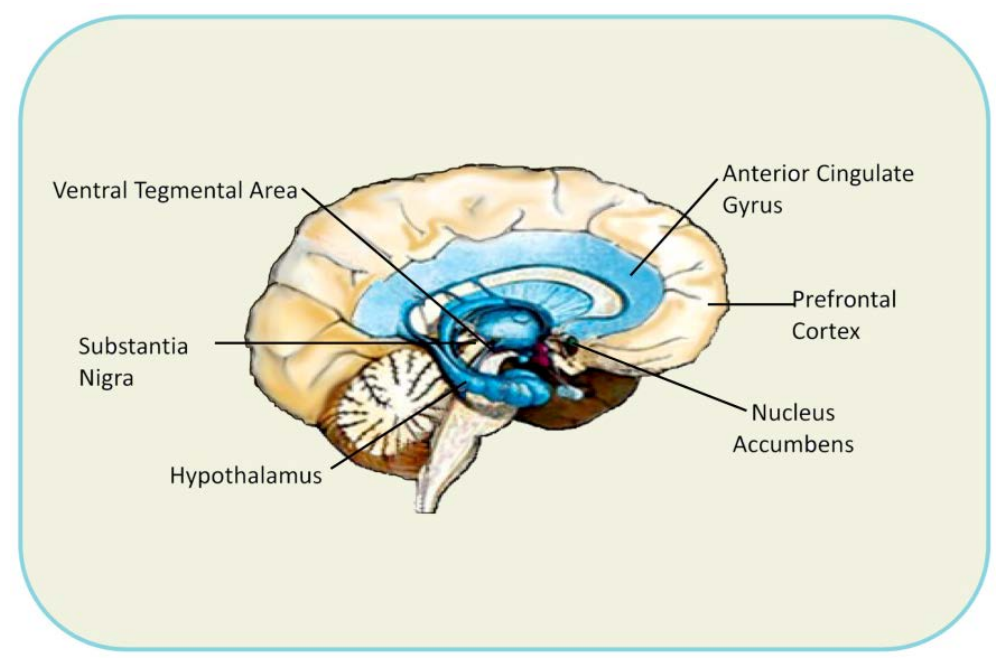

(a)

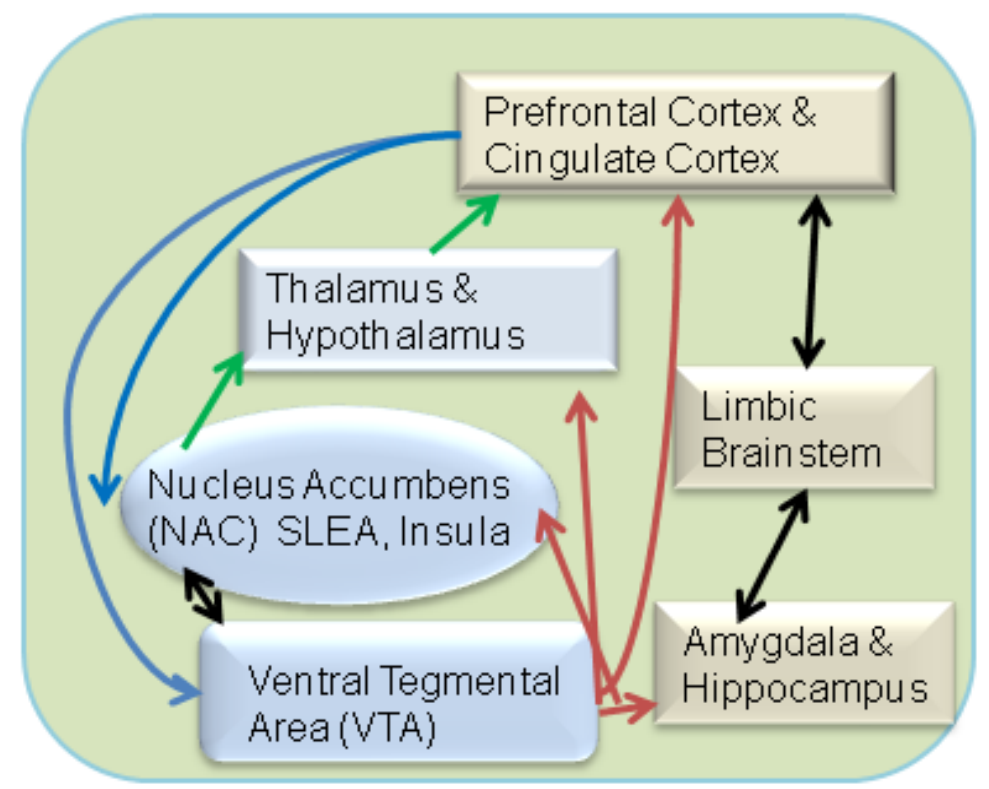

(b)

Figure 1. (a) Brain reward sites; (b) Extended brain reward circuitry (Blum et al. 2013 with permission [165]).

stimulates DA receptors (D1-D5), resulting in stress reduction and feelings of well being [13] [42]. Literature consensus shows that dopaminergic activation is necessary in persons when brain reward cascade or circuitry dysfunction causes a hypodopaminergic trait, especially in the DA system and potentially through certain polygenic or genetic variants [43]. Multiple drug seeking behaviors occur because of such a trait [13] [21] [27] [44]-[46]. This phenomenon occurs because of the neuronal release and activation of brain DA caused by psychostimulants like cocaine, nicotine, glucose, and marijuana, as well as alcohol and narcotics which may subsequently increase craving behaviors [47].

Further support of this notion is derived from the first report by Blum et al. [48] and other subsequent work [49] [50] showing an association of the dopamine D2 TaqA1 allele with severe alcoholism and other work which found decreased D2 receptors in carriers of the A1 allele [20] [51]. A recent multiple population study [52] from the National Institute on Alcohol Abuse and Alcoholism [NIAAA], supported a role of the D2 Dopamine Receptor gene (a haplotype block at 25.8 kb region) in Substance Use Disorder (SUD) [alcohol and heroin]. 


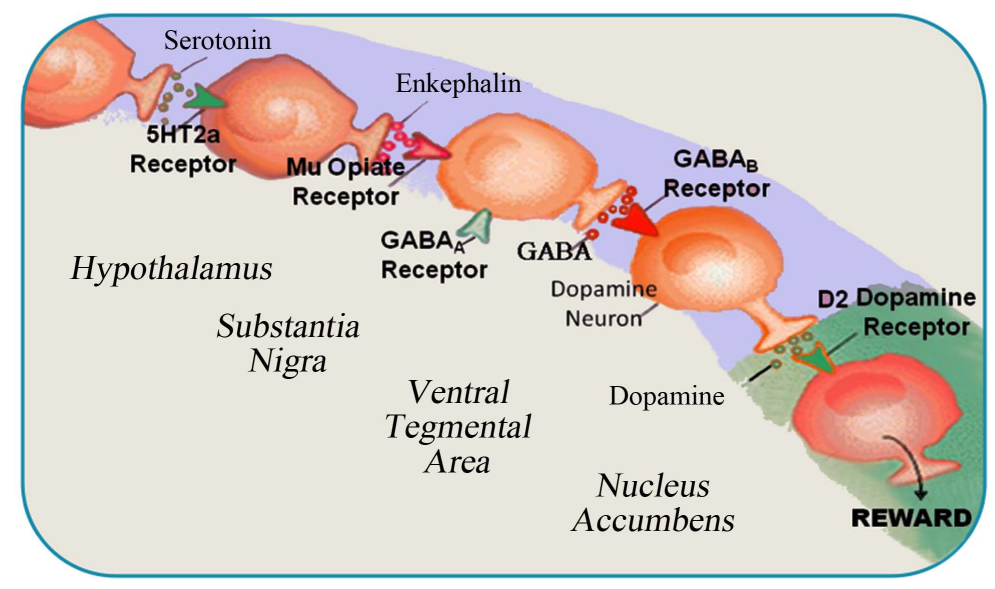

Figure 2. Brain Reward Cacade (with permission [165]). Serotonergic genes and addictive behavior.

Utilizing positron emission tomography (PET) others have found substantial lower levels of D2 receptors in alcohol and drug dependent subjects compared to non-dependent individuals [53]. Moreover, Volkow's group found that subjects with high levels of D2 receptors did not like the effects of psychostimulants, while individuals with low D2 receptors enjoyed the effects of psychostimulants [21]. In animals, overexpression of the D2 receptor via vector delivery of the D2 gene directly into the NAc resulted in significant reduction of alcohol consumption [54] [55].

Propensities toward certain behaviors may be at higher risk when an individual lacks D2 receptors, including compulsive, impulsive, and addictive behaviors, such as substance use, including severe alcoholism and cocaine, marijuana, heroin and nicotine use; glucose binging; sex addiction; pathological gambling; ADHD; chronic aggression; Tourette's Syndrome, autism; post-traumatic stress disorder; conduct disorder; schizoid/avoidant cluster; energy expenditure; antisocial behavior and personality disorders; sensation-seeking; glucose metabolism; lying; and many other behavioral addictions [56]-[71]. Furthermore, above average D2 receptor availability may help protect against alcoholism in non-alcoholic individuals of alcoholic families. Volkow et al. found significant associations between metabolism and D2 receptors in frontal regions of the brain, regions important in executive control and emotional reactivity, suggesting that alcoholism can be protected against by high levels of D2 receptors through reflating of circuits involved in behavioral response inhibition and emotion control [72].

In an attempt to explain the impairment of the reward cascade due to multiple genes and environmental stimuli, i.e. pleiotropism, and the resulting aberrant behaviors, Blum et al. united this hypodopaminergic trait under the term "Reward Deficiency Syndrome" (RDS) [37] (see Figure 2).

Lesch, in a 2005 study investigating the link between serotonin and alcohol dependence, characterized alcohol dependence as the uncontrolled, frequent and compulsive consumption of alcohol with associated destructive and maladaptive behavior; a clinically and etiologically heterogenous, pleiotropic syndrome with medium to high heritability; sharing neurobiological pathways with certain psychiatric disorders, including pathways of reward, anxiety and stress response, and behavioral control [73]. Adaptive changes caused by alcohol in brain function offer the basis for withdrawal, tolerance, craving, and emotional disturbance [73]. Pyschobiological trait differentiation for addictive behavior which reflects neurobiological processes is necessary in determining genetic alcohol dependence susceptibility [73]. Deficits in central serotonin (5-HT) are hypothesized to play a role in alcohol dependence pathogenesis through motivational behavior modulation, neuronadaptive processes modification, and subsequent emotional disturbances [73]. Many variations of genes that encode transporters, enzymes, and receptors of the 5-HT system have been investigated as risk factors for alcohol dependence, with primary focus on the transporter gene (5-HTT); 5-HT-related behaviors, like aggression, suicide and impulsivity have been linked to alcohol dependence vulnerability [73]. Furthermore, a regulatory 5-HTT variant involved in anxiety traits, due to its role in the neurotransmission of serotonin, has been implicated as a key player in depression etiology and plays a role in alcohol dependence development risk, including suicide and antisocial tendencies [73]. Other important associations have occurred with the 5-T2a receptor as well. Genotype-endophe- 
notype associations are potentially accessible to molecular and functional brain imaging, as suggested by the modulatory effect of 5-HTT allelic variation function on emotional stimuli responses by limbic circuits [73].

These findings have substantial implications and help elucidate the role of emotional stimuli on brain response and genetic risk to alcohol dependence [73].

In alcoholics, serotonergic genes associate with major depression. Nellissery et al. determined that short allele frequency in patient subject groups was similar to former reported samples for subjects with unipolar depression, and furthermore determined, with respect to controls, it was significantly more common $(\mathrm{P}=0.045$; $\operatorname{chi}(2)(1)=$ 4.02; short allele frequency, 45.8\%) [74].

By using techniques such as gene knock-out, gene overexpression and gene deletion, investigating existing mutants, and through use of other genetic modifications, approximately 100 genes have been investigated for their association with ethanol in mice [75]. The targeted genes investigated vary in function, among them signaling molecules, neurohormones and players in important neurotransmitter systems, yet all the genes studied are primarily expressed in the brain [75].. Review of these genes responses to ethanol supported the role of gabernergic, dopaminergic, serotonergic and cannidbinoidergic genes in alcoholism [75]..

In regards to the specific serotonergic receptors involved, the results are inconclusive, with both negative and positive associations of 5-HTT2a, 5-Htt2b and 5-Htt2c [76]-[86].

\subsection{Neurotransmitter Metabolizing Enzyme Genes and Addictive Behavior}

\subsubsection{MOA}

Playing an important role as an enzyme in neurotransmitter metabolism, monoamine oxidase A (MAO A) offers several polymorphisms, among them a 30-bp promoter region VNTR (MAOA- $u$ VNTR) [87]. Efficiency is dependent on the number of repeats of alleles; i.e. alleles containing 3.5 or 4 repeats are twice to ten times as efficient as the 3-repeat allele [87]. The 3-repeat allele has been associated through clustering with certain behaviors, including impulsivity, alcoholism and antisocial personality [87]. Moreover, in a study with European descent Brazilians $(n=125)$ and controls $(n=235)$ these associations were confirmed, in which the 3-repeat allele associated with alcohol dependence $(\mathrm{P}<0.05)$; with earlier alcoholism onset $(\mathrm{P}<0.01)$; with an increased quantity of antisocial symptoms $(\mathrm{P}<0.02)$; and with a co-morbidity of drug abuse in alcoholics $(\mathrm{P}<0.05)$ [87].

Moreover, Taq1 A1 allelic presence in the dopamine D2 receptor (DRD2) gene and reduced platelet monoamine oxidase B (MAO-B) activity are both independent genetic and biological markers for alcoholism [88]. The relationship between MAO-B platelet activity and DRD2 Al allelic presence was investigated in a 2000 study, with a subject group of middle-aged Caucasian men $(n=37)$ with daily consumption of ethanol at $85 \pm 57 \mathrm{~g}$ [88]. The results of this study implicates a reduction in MAO-B platelet activity in alcoholics who carrier the DRD2 $\mathrm{Al}$ allele, this relationship persisted in subject groups when controlling for DSM-IV fulfillment of alcohol dependence criteria $(\mathrm{n}=27)$ [88].

In other studies concerned with co-morbidity of anti-social personality and alcoholism, positive findings of association with MOA gene polymorphisms were observed. When comparing the prevalence of the low-activity 3-repeat allele in male alcoholics, 7 of 31 alcoholics with anxious or depressive disorders were carriers of the allele, while 30 of 59 antisocial personality disorder alcoholics were carriers $(23 \%$ vs. $51 \%$; $\mathrm{P}=0.02)$ [89]. Similarly, female alcoholics with anxious or depressive disorders tended to carrier the 3-repeat allele less frequently than female alcoholics that did not have these symptoms (29\% vs. $53 \% ; \mathrm{P}=0.09$ ) [89]. The result of this study indicates that the $M A O A$ 3-repeat allele may play a modest role in under- and over-reactive behaviors as antecedents of alcoholism [89].

Additionally, an association between the liability to early onset alcoholism/substance abuse and a MAOA gene (MAOCA-1) dinucleotide repeat length polymorphism was investigated utilizing polymerase chain reaction (PCR). A significant association was found in males, in which the presence and absence of "long" alleles (with repeat length exceeding 115bp) correlated with a reduced age for substance abuse onset and higher disorder risk [89]. However, we are exploring the 3.5 and 4 alleles for association with a "hypodopaminergic" trait as reflected in the GARS test.

\subsubsection{COMT}

Catecholamine-O-Methyltransferase (COMT) is an enzyme which plays a critical role in DA metabolism [90]. The variability of human COMT enzyme activity is monitored by a functional polymorphism [90]. In example, low or high activity variants of the COMT enzyme have either a methionine or valine residue bound at amino 
acid 158 of the COMT protein, respectively [91]. Approximately 25\% of white individuals are homozygous for the low activity allele (genotype: LL), with DA metabolism activity increasing 3 to 4 fold in the high activity homozygotes (genotype: $\mathrm{HH}$ ) [91]. The white individuals with $\mathrm{HH}$ genotype account for approximately $25 \%$ of whites [91]. Congruently, individuals heterozygotic (genotype: LH) with both low and high activity alleles have an intermediate phenotype, with moderate levels of COMT activity [91].

Evidence shows that this functional polymorphism in the COMT gene is associated with certain mental disorders such as obsessive-compulsive disorder and substance abuse, rapid cycling bipolar disorder, and schizophrenia with increased violent behavior. It has been conjectured that the allelic variants at the COMT locus are candidates in the etiology of SUD. Ethanol-induced euphoria is associated with rapid increase in the release of DA in the limbic areas. While others have postulated that individuals homozygous for low activity COMT alleles (resulting in a low DA inactivation rate) may be at an increased risk of developing alcohol abuse or dependence as compared to heterozygotes and high activity homozygotes, this hypothesis has not been confirmed. In this theory individuals with a low activity (LL) COMT genotype may experience a longer lasting and more effective DA release in the brain. This might increase the reward of alcohol drinking and lower the threshold of pleasure-seeking behavior. There are studies and others which support this notion including the work of Long et. al. [92] in alcohol dependence in an American Indian population; Tiihonen et al. [93], in type 1 alcoholism in a Finish population and in Finish social drinkers.

Recent research also shows an association of certain COMT polymorphisms and novelty seeking. This is important because measurable personality traits provide diagnostic and risk assessment opportunities for psychopathology [94]. Higher levels of novelty seeking play important roles in SA pathogenesis, novelty seeking a fundamental characteristic of temperament [94]. Moreover, COMT is necessary for the inactivation of DA [94]. A recent study aimed at evaluating whether the Val158Met polymorphism of the COMT gene in methamphetamine dependent patients was associated with their novelty seeking scores [94]. The study determined that of Caucasian Czech methamphetamine dependent patients (females $=10$; males $=27$; average age $=23.6 \pm 3.8$ years), average novelty seeking scores were significantly higher in Met allele homozygotic and heterozygotic patients $(\mathrm{N}=28)$ than in the $\mathrm{Val}$ allele homozygotes $(\mathrm{N}=9)$ with a p value equal to 0.042 [94]. These results led Hosak et al. to conclude that patients with Met allelic COMT genes would be associated with higher endogenous prefrontal cortex synaptic DA and lower COMT activity [94]. This effect would reduce NAc DA neurotransmission, requiring increased stimulation activity [94]. However, it is the VAL allele that leads to a "hypodopaminergic" trait as reflected in the GARS test.

\subsection{Opioidergic Genes and Addictive Behavior}

Opioids act on three major classes of opiate receptors: mu, delta and kappa. These G-protein-coupled receptors, which inhibit adenylyl cyclase are distributed throughout the central nervous system (CNS).

Blum et al. [95] was the first group to suggest an opiodergic mechanism as a potential candidate in alcoholism and alcohol abuse. While this hypothesis, based on narcotic antagonism of ethanol's pharmacological effects, met with controversy, now it is well established that opioids play a significant role in alcohol dependence and withdrawal. In fact it has been shown both in humans and animals studies that alcohol induces a reduction in brain enkephalin and b-endorphin levels [96]-[98]. These findings support the opioid deficiency hypothesis proposed by Blum and Topel [99].

The measurement of decreased Beta-endorphin baseline activity appears to fulfill two of the reviewed criteria for a trait marker of alcoholism. These are lower B-endorphin levels in alcoholics and decreased opioid receptor density in Children of Alcoholics (COA) [100]. However, the measurement of increased Beta-endorphin responsiveness seems to fulfill three such criteria in that it is heritable, it is present in alcoholics, and it is state independent (present in COA) [101]. A similar finding was obtained in COA's with regard to the presence of the $D R D 2$ gene $A 1$ allele [102]. This takes on even greater significance when one considers the evidence whereby activation of ventral tegmental area mu opioid receptors, or of NAc mu and delta opioid receptors, increases the extracellular NAc DA concentration [100].

\subsection{Gabaergic Genes and Addictive Behavior}

Gamma-amino butyric acid (GABA) acts on the $\mathrm{GABA}_{\mathrm{A}}$ receptor, which is a transmitter gated chloride channel. $\mathrm{GABA}_{\mathrm{A}}$ receptors are composed of three subunits: alpha, beta and gamma. There is evidence that a lower base- 
line plasma level of GABA seems to fulfill two criteria for the identification of a vulnerability marker for alcoholism. Inter-individual differences in measures of baseline plasma level of GABA appear to be heritable and alcoholics show reduced levels of GABA in there plasma. Similarly, measures of decreased GABA receptor responsiveness appear to fulfill two trait marker criteria. Decreased GABA receptor responsiveness seems to characterize both alcoholics and their children [101].

Alcohol also induces an effect on gabaergic genes and addictive behavior, by raising neurosteroid levels, increasing GABA release, and potentially playing a role in function enhancement of the GABA(A) receptor subclass which has low conductance to chloride, insensitivity to benzodiazepines, high GABA and neurosteroid affinity, and a location which is extrasynaptic [103]. It has been hypothesized that differences in the GABA(A) receptor subunit genes may potentially contribute to risk for developing alcoholism, particularly with respect to environmental risk factors [103]. Time-dependent changes in the receptor densities of GABA(A) in the brain and gene expression levels of subunits both play a part in alcohol dependence through GABA(A) receptor withdrawal-related insufficiencies [103]. Interestingly, GABA levels of the cerebral cortex do not decrease with acute withdrawal [103]. The aphasic constituent of GABA function is enhanced by detoxification through assistance of benzodiazepine [103]. New treatments are being developed that can affect the neurotransmission of GABA through the tonic components of GABA(A) receptors, insensitive to benzodiazepine [103]. The functional disturbances in GABA as a result of withdrawal can be reduced in the brain through smoking, which explains co-morbidity alcohol and nicotine dependence [103]. Recovery of GABA systems is possible with persistent sobriety [103].

In a 2007 study, Lappalainen et al. investigated mutations in a gene which encodes an enzyme important in the synthesis of GABA, glutamate decarboxylase-2 (GAD2), for association with alcohol dependence [104]. The $G A D 2$ gene was screened for using dHPLC for sequence variants $(\mathrm{n}=96)$ [104]. Various different single nucleotide polymorphisms (SNPs) were discovered; among them were four unique, rare polymorphisms [104]. Of GAD2 SNPs, thirteen were genotyped in 100 Russian male controls and 113 alcoholic dependent Russian males; the results determined that the GAD2-243 A > G SNP (rs2236418) slightly associated with AD (genotype P = 0.008 , allele $\mathrm{P}=0.038$ ) [104]. 138 additional alcohol dependent Russian males were genotyped for Gad2-243 A > $\mathrm{G}$, the results of which supported the SNP association with AD (genotype $\mathrm{P}=0.0009$, combined sample allele $\mathrm{P}$ $=0.038$ ) [104]. When these results were evaluated in a new context, 538 European-American (EA) college students ( $\mathrm{AD} \mathrm{n}=235$, control $\mathrm{n}=310$ ), GAD2 did not associate alcoholism [104]. These findings suggest that EAs do not have $G A D 2$ variation as a risk factor for AD, the $G A D 2-243 \mathrm{~A}>\mathrm{G}$ functional promoter may contribute to vulnerability for $\mathrm{AD}$ in some groups, and/or the severity of AD determines the relationship between this SNP and risk for AD [104]. Furthermore, it has been suggested that the DRD2 A1 allele also depends on the severity of $\mathrm{AD}$ [48].

With regard to the reward circuitry it is very interesting that Young et al. [105] studied the relationship between the GABA and dopamine gene systems. In this regard, there have been some significant identifications of markers for $\mathrm{AD}$ in molecular genetic research, among them the DRD2 receptor and the beta3 subunit of the $G A B A(A)$ receptor (GABRB3) [105]. It is still not understood whether genetic risk makes it harder to resist alcohol or if it results in alcohol expectancies becoming stronger [105]. Young et al. investigated alcohol expectancy associations in $56 \mathrm{AD}$ patients, determining whether individual patients had the $D R D 2 \mathrm{~A} 1+$ (A1A2 and A1A1) or DRD2 A1- (A2A2) genotype, GABRB3 G1+ (G1 non-G1 and G1G1) or GABRB3 G- (non-G1 non-G1) genotype, and by assessing drinking refusal self-efficacy (DRSE) and mood-related alcohol expectancy (AE) in all patients utilizing the Drinking Expectancy Profile developed in 1996 at the Brisbane Behavior Research and Therapy Centre [105]. The results of the study showed that under social pressure, patients with the A1+ allele of the DRD2 gene had significantly lower DRSE scores than patients with the A1- allele [105]. Congruently, in situations of social pressure, patients with the G1+ allele of GABRB3 had lower DRSE than those with the G1GABRB3 genotype [105]. Moreover, GABRB3 G1+ genotypic patients also had lower DRSE when under negative affect and had greater $\mathrm{AE}$ as the result of changes in negative affect, than the GABRB3 G1- genotypic patients [105].

Radel et al. investigated other GABA(A) receptors and their associations with $\mathrm{AD}$, in two large populations (Southwestern Native American $n=433$, Finnish $n=511$ ) [106]. A sib-pair linkage was observed in Finns of GABRG2 to AD ( $\mathrm{P}=0.008)$; furthermore, the $G A B R B 21412 T$ allele associated with $\mathrm{AD}$ in both groups (Southwestern Native American P = 0.008, Finnish P = 0.01) and GABRA6 $1519 T$ allele also associated with $\mathrm{AD}$ in both groups (Southwestern Native American $\mathrm{P}=0.03$, Finnish $\mathrm{P}=0.01$ ) [106]. In both subject populations, 3-locus haplotype linkage disequilibrium mapping supported a $G A B A(A)$ gene cluster region $\mathrm{AD}$ locus, 
with signals most significant for 3-locus haplotypes including 1 or more GABRA6 polymorphisms and with the GABRA6 3-locus haplotype initiating the peak signal (Southwestern Native Americans $\mathrm{P}=0.02$, Finnish $\mathrm{P}=$ $0.004)$ [106]. Moreover, Radel et al. determined a sib-pair linkage in Finns of $5 q 34 G A B A(A)$ receptor genes to AD [106]. Haplotype localization, in each population, brings to attention the Pro385Ser GABRA6 polymorphism as well as two additional GABRA6 polymorphisms [106].

\section{Gene Therapy Targets}

Research investigating genetic targets for evaluating alcoholism risk, principally genes of enzymes involved in alcohol metabolism, has developed compelling support. In example, protection against alcoholism and heavy drinking has been seen for variants of alcohol dehydrogenase that elicit higher oxidation of alcohol, as well as variants of acetaldehyde dehydrogenase that elicit lower oxidation of acetaldehyde [107]. Murine models have been developed which initiate certain behaviors from strong genetic influences to ethanol, including tolerance development, susceptibility to alcohol withdrawal and alcohol drinking preference [107]. The results of research into the physiological response to ethanol has implicated various neuro- and genetic pathways as being involved, including dopamine, serotonin, glutamate, opioid and GABA pathways [107]. Analysis at a genetic level has implicated the involvement of many genes in genetic risk for the effects of alcohol, including DRD2, tryptaphan hydroxylase, neuropeptide $\mathrm{Y}$ and serotonin $1 \mathrm{~b}$ and 2a receptors [107].

Other risk factors for alcoholism include certain personality traits, such as impulsivity, which involve behavioral inhibition [107]. The aggregate effect of these traits, along with genetic predispositions, differential biological metabolism of alcohol and physiological effects of alcohol in the body, implicate alcoholism as pharmacogenetic in nature [107]. Additionally, various environmental factors also influence alcohol ingestion, further complicating the clinical understanding of alcoholism [107].

\section{Cascade Hypothesis of Reward}

In the cascade hypothesis of reward dependence and SUD genetic anomalies, enduring stress, or persistent abuse of certain drugs (i.e. alcohol, cocaine, heroin etc), can lead to a substance seeking behavior which is self-sustaining, in both animals and humans. Various studies support the cascade theory through animal models [108]-[110]. Moreover, studies have been conducted on alcohol-preferring (P) and non-preferring (NP) murine lines [111]-[114]. This research found that the $\mathrm{P}$ rats have the following neurochemical profile:

- fewer hypothalamic serotonin neurons;

- $\quad$ higher hypothalamic enkephalin levels (resulting from lower release);

- $\quad$ more NAc GABA neurons; and

- $\quad$ reduced mesolimbic DRD2 densities.

This four-part cascade is a sequence which leads to the net reduction of dopamine release in the principle area of reward. Li et al. confirmed these findings by reducing craving behaviors through increasing synaptic serotonin supply or direct dopamine D2 receptor stimulation. Agonists of the D2 receptor were able to reduce the intake of alcohol in high alcohol preferring rats, and antagonists of the D2 receptor increase the intake of alcohol in this subject group [115]. Moreover, in humans bromocryptine significantly reduces relapse in DRD2A1 positive carriers compared to $D R D 2 A 2$ carriers [116].

Human clinical trials have been conducted in support of the cascade theory of SUD, in which a precursor amino acid technique is utilized through neuronutrient administration, enhancing brain tryptophan and inhibition of enkephalinase- these studies indicated reductions in alcohol, polydrug, cocaine and sugar craving; reductions in stress, AMA and facilitated recovery rates; reductions in relapse rates in DUI offenders; enhancements in focus; and enhancements in memory [117]-[129].

It is well known that one important enzyme involved in the destruction and clearance of pre-synaptic DA release is COMT which reduces active DA in the synapse [130]. It is also known that the COMT gene has been associated with SUD [131]-[133]. Therefore, we decided to add Rhodiola rosa, a known natural COMT inhibitor, to KB220Z amino-acid therapy regimen to enhance dopaminergic activity, especially at the synapse [134].

\subsection{Targeting the Genetically Impaired Reward Deficiency Circuitry by DNA Directed Nutraceutical Induced Brain Neurotransmitter Repair}

We theorize that by combining neurotransmitter synthesis promoters, opioid peptide catabolism inhibitors, brain 
serotonin synthesis enhancers and COMT inhibitors in a nutraceutical formulation, the product so conceived will significantly reduce aberrant substance seeking behavior in humans via four molecular mechanisms:

Enhancement of brain neurotransmitter synthesis by amino-acid precursors [135] [136];

Enhancement of hypothalamic enkephalins by decreasing catabolism by D-phenylalanine [137];

Enhancement of brain serotonin by a tryptophan concentrating mineral such as chromium [138];

Enhancement of synaptic dopamine by decreasing catabolism by Rhodiola [134].

\subsection{Evidence for the Effects of KB220 on Addictive Behavior}

The formula for KB220 is designed to exploit anti-craving, additive and potentially synergistic mechanisms, the ingredients of which act through a series of processes to enhance neurotransmitter activity and mitigate behaviors associated with RDS. Caution should be taken in the interpretation of these results.

- Several experiments in mice have shown induced enkephalin brain changes, both through d-phenylalanine administration (18 days at $500 \mathrm{mg} / \mathrm{kg} /$ day) and/or administration of its metabolite, hydrocunnamic acid (25 mcg intracerebral ventricular injection) [108]. Utilizing the same dosages, alcohol preference in the 14 day preference test and in acceptance was significantly reduced by these enkephalinase inhibitors.

- Defrance et al. has determined that through a combination of DL-phenylalanine (1500 mg/day), chromium picolinate (360 micrograms/day), L-glutamine (300 mg/day), L-tyrosine (900 mg/day) and other co-factors, electrophysiological changes could be induced (with enhancement of focus and memory) in healthy volunteers [129].

- Blum et al. determined that DL-phenylalanine (2760 mg/kg/day), pyridoxal-5-phosphate (30 mg/day), L-glutamine (150 mg/day) and L-tryptophan (150 mg/day) administered to inpatient alcoholics led to tremors ceasing at 72 hours, lower building up to drink scores, MMPI results indicating no severe depression (in comparison to the control group, 245 score) and requiring no PRN benzodiazepines, (0\% vs. 94\%) [121], and;

- A combination of L-tryptophan (150 mg/day), DL-phenylalanine (2760 mg/day), pyridoxal-5-phosphate (30 $\mathrm{mg}$ /day) and L-glutamine (150 mg/day) administered to poly-substance abusing inpatients, via a placebocontrolled, double-blind study, resulted in a six-fold withdrawal against medical advice rate (AMA) reduction, emotional and physical score improvement, treatment recovery enhancement and significant stress reduction [119].

- A combination of L-tryptophan (400 mg/day), DL-phenylalanine (1500 mg/day), pyridoxal-phosphate (20 $\mathrm{mg}$ /day), L-glutamine (300 mg/day), and L-tyrosine (900 mg/day) administered in a 30 day treatment period to inpatient cocaine abusers resulted in a significant drug hunger and withdrawal AMA reduction, treatment program retention improvement, and a reduction in the inpatient need for benzodiazepines, as compared to controls [123].

- A combination of Chromium, DL-phenylalanine, pyidoxyl-5-phosphate, L-glutamine and L-tyrosine was administered over a ten-month period to DUI offending outpatients (cocaine addicts and/or alcoholics); controls were administered a vitamin complex, containing vitamin C and B-complex [120]. In comparison to the control group, the experimental group had significant enhanced recovery and relapse rate reduction [120]. In alcoholics, experimental group retention rates were $87 \%$, with $47 \%$ for controls; in cocaine abusers retention rates were $80 \%$ for the experimental group and $13 \%$ for controls [119]-[121]. Alcoholic and cocaine abuser experimental groups were differentially dosed; alcoholics were treated with chromium picolinate (360 micrograms/day), DL-phenylalanine (2760 mg/day), pyridoxal-5-phosphate and L-Glutamine (150 mg/day); cocaine abusers were treated with DL-phenylalanine (1500 mg/day), pyridoxal-5-phosphate (20 mg/day), L-glutamine (300 mg/day) and L-Tyrosine (900 mg/day) [119]-[121].

- Utilizing the amino acid and enkephalinase inhibitory therapy, a combination of DL-phenylalanine (1500 mg/day), pyridoxal-5-phosphate (20 mg/day), L-glutamine (300 mg/day) and L-Tyrosine (900 mg/day) administered to cocaine addict outpatients led to significant improvements in withdrawal symptoms and cocaine craving [139];

- Sole chromium picolinate administration in two placebo-controlled double-blind experimental studies at doses of $200 \mathrm{mcg}$ or $400 \mathrm{mcg}$, resulted in body fat loss, nonfat mass gain, and improvement in body composition [126]-[128]. In addition, carriers of the DRD2A1 allele did not respond to chromium picolinate in terms of body composition parameters compared to carriers of the DRD2A2 allele. 
- A combination of L-tryptophan (150 mg/day), DL-phenylalanine (2700 mg/day), pyridoxal-5-phosphate (30mg/day), and L-glutamine (150 mg/day) was supplemented to an experimental group of high carbohydrate binging outpatients $(n=27)$, with controls not receiving the supplement, and weight loss was measured in the two groups following a 90-day diet-controlled supervised treatment regimen, where female caloric daily intake was limited to 800 calories and male caloric daily intake was limited to 1000 - 1200 calories [124]. Following the 90 day treatment regimen, the supplemented group lost an average $26.95 \mathrm{lbs}$, while the control group only lost $10 \mathrm{l}$ bs [124]. Furthermore, relapse rates (over the 90 day period, patients lost less than $15 \mathrm{lbs})$ were reduced for the experimental group in comparison to controls ( $8.0 \%$ and $18.2 \%$, respectively) [124].

- A combination of chromium picolinate (200 micrograms/day Cr), L-tryptophan (150 mg/day), DL-phenylalanine (2760 mg/day), pyridoxal-5-phosphate (30 mg/day), L-glutamine (150 mg/day) and carnitine (60 $\mathrm{mg}$ /day) was administered in a non-randomized double-blind open trial, with a Centrum vitamin control, to an obese patient population $(n=247)$ over a 2-year treatment period [125]. In comparison with the control group, the supplemented KB220Z/Centrum group showed a reduction in food craving in males and females (63\% and $70 \%$, respectively) and a reduction in binge eating in males and females ( $41 \%$ and $66 \%$, respectively) [125]. Notably, only $14.7 \%$ of lost weight was regained in the experimental group [125]. Multiple regression analysis showed that two factors significantly predicted weight gain following two years with KB220Z treatment, among them binge eating score and morbid obesity [125]. Although not statistically significant, KB220Z treatments elicited improved results for patients with histories of familial chemical dependence [125].

- Blum et al. hypothesized that the combination of a narcotic antagonist with amino acid therapy would enhance detoxification in recovering addicts [140]. Moreover, in methadone patients detoxifying with Trexan ${ }^{\circledR}$, a narcotic antagonist (Duponr, 5 Delaware), compliance may be improved with supplementation of D-Phenylalanine, an enkephalinase inhibitor, and L-amino acids, the neurotransmitter precursors that promote release of neuronal dopamine [140]. Research suggests that NAc adenoviral vector $D R D 2$ gene delivery and subsequent increases in NAc dopamine $\mathrm{D}_{2}$ receptors, significantly reduced the alcohol intake (64\%) of rats preferring ethanol as well as the ethanol preference of rats (43\%); these phenomena normalized upon the return to baseline of $D R D 2$ levels [141]. Interestingly, overexpression of $D R D 2$ in non-preferring ethanol rats elicited similar reductions in alcohol intake (75\%) and preference (16\%) [141]. These findings implicate that alcohol abuse can potentially be protected against with increased levels of $D R D 2$ [48] [49] [102]. In several studies, the A1 allele of the DRD2 gene associates with heroin addicts. Furthermore, opioid dependence has been associated with other polymorphisms of the dopaminergic receptor gene; namely, the DRD4 receptor 7 repeat allele which was significantly and disproportionally large in an opioid dependent study group, conferring a 2.46 relative risk. These findings were confirmed in heroin addicts of Han Chinese control case, for 7 and 5 repeat alleles. Homozygotes of DRD3-Bal 1 significantly associated with French heroin addicts [49]. Moreover, an NIAAA study has strongly implicated $D R D 2$ as a susceptibility gene for SA across many populations [52]. Furthermore, enkephalinase inhibition and amino-acid therapy have been utilized in several human trial studies eliciting a reduction in cocaine, sugar, alcohol and opiate craving behaviors [119]-[125].

- With the development of a rapid detoxifying method for heroin and methadone addicts, by using Trexan ${ }^{\circledR}$, combination treatment therapies have been developed to further improve addict recovery. By combining Trexan ${ }^{\circledR}$ therapy with amino acid therapy, compliance to taking Trexan ${ }^{\circledR}$ is significantly increased [140]. The amino acid therapy was a combination of chromium picolinate (360 micrograms/day Cr), DL-phenylalanine (2760 mg/day), pyridoxal-5-phosphate (30 mg/day) and L-Glutamine (150 mg/day) [136]. For example, without the combination of amino-acid therapy, the average days of compliance with taking Trexan ${ }^{\circledR}$, as calculated for 1000 patients, is 37 days; while, 12 subjects taking both Trexan ${ }^{\circledR}$ and amino acid therapy were relapse-free or complied with the treatment therapy for 262 days on average $(P<0.0001)$ [140]. This offers a promising method for rapid detoxification in chronic methadone patients, with delta receptor blocking by a narcotic antagonist, enkephalinase inhibition and amino-acid therapy. These findings implicate treatment and relapse-prevention opportunities for alcohol and opiate dependent individuals as well. Further investigation into the coupled effects of these agents along with sublingual buprenorphrine, a partial opiate mu receptor agonist, is worthwhile.

- Julia Ross, author of The Diet Cure (Penguin UK, Au, and USA, 2000; Viking Press USA, 1999), conducted 
a small study utilizing enkephalinase inhibition and amino-acid therapy to treat eating disorders for outpatients of Mill Valley, CA [142]. A combination of chromium, L-tryptophan, 5-hydroxytryptophan, DLphenylalanine, L-glutamine, L-tyrosine and Vitamin B6 were tailored made for and administered to patients with eating disorders [142]. Nine months to three years later, follow-up screening of six random female patients with eating disorders (three of whom also had chemical dependence) was conducted to determine efficacy of combining peer support, education and conventional counseling with nutritional elements (digestives enzymes, amino-acids, low-carbohydrate diet with adequate nutrients and calories, and amino-acids) in therapy [142]. This evaluation found significant initial improvements in freedom from compulsive behavior and mood and ideation in all screened patients [142]. One patient relapsed in a six month period, while the five other screened patients all met or surpassed expectations [142]. In response to this investigatory treatment for eating disordered patients, 100 additional patients were evaluated, in which $98 \%$ of patients experienced significant benefits in mood and reductions in carbohydrate craving (among other substances of abuse) [142]. This work further implicates the importance of utilizing targeted nutritional procedures in combination with conventional therapies to enhance treatments for RDS intransigent patients [142].

- In a Las Vegas clinic, a combination of Chromium dinicotinate glycerate (1000 micrograms/day), 5-hydroxytryptophan (20 mg/day), DL-phenylalanine (2700 mg/day), L-glutamine (350 mg/day), L-Tyrosine (750 mg/day), B6 [20\% Pyridoxal-5-phosphate and 80\% Pyridoxine], Rhodiola rosea (3\% rosavin) (66 mg/day), Huperzine A (150 micrograms/day), DMAE (40 mg/day); a combination of vitamins (B12, Pantothenic acid, Biotin, C, E, Thiamin, Niacin, Manganese, Riboflavin, Magnesium, folic acid, zinc and Calcium); and a focus blend, herbal calming blend or mood enhancing blend, were administered to outpatients $(n=76)$ [134]. The dosages and ingredients depended on abuser type, taking into account ADHD diagnosis [143]. In regards to relapse rates, for CCD: 2 of 15 dropped out of the program within a year, eliciting a $13.33 \%$ group relapse; for CC: 11 of 43 patients dropped out of the program within a year, eliciting a $23.2 \%$ group relapse; for FCS: 2 of 10 patients dropped out of the program within a year, eliciting a $20.0 \%$ group relapse; and for SR: no patients of 8 dropped out of the program within a year, eliciting a $0.0 \%$ group relapse. For the entire program, relapse rates of the total subject group $(n=76)$ was $19.9 \%$ group relapse, in which 15 patients dropped out of the program. Interestingly, 11 of the 15 drop outs (73.3\%) abused methamphetamines.

Neurotransmitter deficiencies can fortunately be mediated by ensuring adequate amino acid availability, such that certain neurotransmitters have the building blocks necessary for manufacture; the brain instigating the ofinterest neurotransmitter manufacture. DNA testing to adapt dosage and inclusion of evidence-based, qualified ingredients for the treatment of RDS, especially for addicts of alcohol, narcotics and other substances, promotes a generalized anti-craving effect.

\subsection{Addiction to Pain Medications in the Workforce}

A common feature of many chronic illnesses and injuries is persistent or recurrent pain of which two potential consequences are analgesic addiction and "pseudoaddiction". Chronic utilization of pain medication often leads to analgesic addiction among pain patients. When it occurs it complicates pain management and is difficult to treat. Assessment of addiction among patients with pain is complex and may be missed [144]. For patients taking opioids for long-term pain, it was argued that physiological dependence is to be expected and more weight should be attached to "maladaptive behavioral changes [145]". When addiction occurs, as previously stated, it significantly impairs the recovery process. Moreover, we are also faced with the problem of what has been coined "pseudoaddiction".

This occurs when patients whose pain is poorly controlled make attempts to obtain analgesia that resemble drug seeking and are interpreted by medical staff as addictive behaviors, compromising pain management and undermining staff-patient trust [146]. Since genuine analgesia addiction is behaviorally similar to "pseudoaddiction", pain management may be similarly impaired and requires a novel approach to reduce pain medication in the injured workforce [147].

Miller et al. investigated whether pain prescription opioid medications worsened or improved medical condition pain syndromes in DSM-IV determined prescription opioid dependent patients and if detoxification enhanced or worsened self-reports and perception of pain in patients taking opioid prescriptions chronically [148]. Miller et al. conducted a retrospective analysis of patients from the Lansing, MI, St Lawrence Hospital Addiction 
Treatment Unit [148]. Selected patients sought voluntary opioid medication detoxification as inpatients, underwent DSM-IV prescription opioid dependence diagnosis, cooperated in self-reported pain evaluations and abstained from opioid medication use [148]. Furthermore, patients were chosen at random from 2001 to 2003 discharges in patient census [148]. The study found significant improvements in pain scores throughout the detoxification process [148]. In example, from admission to discharge, the mean self-reported pain score improved from 5.5 to $3.4(0=$ no pain, $10=$ maximum pain $)$, with a period of detoxification lasting 5 days on average [148]. At admission, higher self-reported pain scores were produced with OxyContin, oxycodone CR, than at discharge [148]. Furthermore, OxyContin patients had significant reductions in levels of pain with decreasing opioid doses than patients using other opioid medications [148]. Less pain was reported during detoxification, and opioid medication abstinence was achieved, by DSM-IV diagnosed prescription opioid dependent patients [148].

Furthermore, in 2001 the lower-bound cost estimate of U.S. opioid analgesic prescription abuse was $\$ 8.6$ billion [149]. The associated costs were in healthcare (\$2.6 billion), criminal justice ( $\$ 1.4$ billion) and workplace (\$4.6 billion) [149]. These figures suggest a rising trend of opioid analgesic prescription abuse, worsening the associated public and monetary burden in the U.S., and further implicating the potential of a global epidemic [149].

\subsection{Brain Dopamine and Pain Mechanisms}

Plastic alterations in encephalic synaptic neurotransmission are hypothesized to contribute to chronic pain. Moreover, cortical and striatal dopaminergic systems have been shown to modulate or transmit pain in animal models. In animal models, dopamine D2 receptors have been suggested as mediating the inhibitory role of dopamine for chronic pain [150] [151].

Hagelberg et al. found that increased putamen D2 receptor availability in healthy volunteers associated with a decreased threshold for cold pain and an increased capacity for modulating pain to conditioned stimuli [152]. High putamen D2 receptor availability and reduced uptake of [18F] FDOPA has been shown in burning mouth syndrome, a persistent orofacial pain condition. The reduction in D1/D2 ratio and increase in the availability of the left putamen D2 receptor in patients experiencing persistent orofacial pain, suggests the involvement of striatal dopaminergic changes, as measured by PET, in the manifestation of orofacial chronic pain [152]. Hypodopaminergic encephalic function may predispose people to reduced pain tolerance; this concept is supported by current research [90]. Moreover, D2 Taq A1 allele carriers may potentially serve as strong candidates for nutrient-based therapies intended to promote encephalic dopamine release [90].

\subsection{Putative Mechanism of Action of the Electrotherapy Device}

The mechanism of the effect of the Electrotherapy device has been formally proposed but may be unclear [153] [154]. However, it has been proposed that the effects of Electrotherapeutic Device and Program, in part, may be due to improvement in tissue circulation among other innate properties of the Electrotherapy device [153]. Deemed as playing a predominant role in disability and pain, persistent inflammation/edema is caused by lymph fluid buildup of large proteins [153]. By promoting a negative lymphatic system pressure, fluid shifts will normalize and tissue homeostasis will be ensured [153]. The Electrotherapy device has been hypothesized to reduce fluid buildup through contraction of red muscle fibers in a milking action [153]. By normalizing the transcapillary shifts in fluid, inflammation of the tissue is reduced, thereby inducing pain reduction [153]. The fluid shift hypothesis was tested in humans by measuring compartmentalized absolute water content of the leg, both preand post-Electrotherapy [153]. From the study, it has been hypothesized that neuromyositis normal function is disrupted in the legs of diabetics and treatments are able to normalize conditions, increasing muscle water content and normalizing water depletion [153]. Moreover, it is speculated that the effect of the Electrotherapy device to further reduce pain may also involve other unique features such as its ability to directly stimulate the small smooth muscle fiber within the lymphatic vessels by stimulating the small red (fatigue resistant) muscle fibers.

We theorize that the mechanisms involved in the effect of the Electrotherapy device include the following: 1) to elicit low tension, non-fatiguing and non-tetanizing muscle contractions for smooth lymphatic muscle as well as skeletal muscle fibers, closely mimicking natural and voluntary contraction of the muscle through low frequency $(2 \mathrm{~Hz}) ; 2)$ to stimulate small fibers through waveform exponential decay and constant activity of the current 
generator; 3) to not activate motor nerves of sensory Delta and C pain fibers or white muscle fibers, thereby removing any pain caused by such stimulation; 4) to effect pain disorders anesthetically when utilized at higher frequency $(60 \mathrm{HZ})$, intrinsically affecting the nerve through nerve fiber sodium pump deactivation inducing an enduring analgesic/anesthetic effect via an accumulative post-synaptic depression. If this hypothesis, based on known mechanisms, is borne out in further studies, the Electrotherapy device may provide an electrotherapeutic option for painful and persistent inflammatory disorder treatment, i.e. Carpel Tunnel, Intervertebral Foramina encroachment, among other disorders [154].

Recent support is derived from published microcirculation studies in the cremaster muscle of rats. In these studies, stimulation with the Electrotherapy device resulted in a 8\% - 12\% increase in vascular diameter which translates to approximately $36 \%$ to $42 \%$ enhanced microcirculation as well as angiogenesis [155]. Preliminary evidence also suggests a nitric oxide vasodilatory mechanism [156].

\section{Evidence Based Medical Support}

Previous studies have shown that Electrotherapy device produced a positive response in a number of published studies related to soft tissue neuropathies in humans and animals. The major finding of these are studies included herein [154]-[162]:

- Thirty-one patients with peripheral neuropathy symptoms were randomized to a control, sham treatment group or electrotherapy group; the results of the study found symptomatic improvement in $83 \%$ of electrotherapy group cases and 38\% of controls [157]. Symptom reduction was significantly improved in the electrotherapy group than in controls $(\mathrm{P}<0.05)$ [157]. Moreover, for patients who were previously in the control group, electrotherapy was able to decrease pain scores [157].

- Long-term efficacy of electrotherapy in pain management was evaluated by Julka et al. [158]. Forty-one patients $(76 \%)$ reported improvements in neuropathic pain $(44.0 \% \pm 4.0 \%$ average improvement) [158]. On an analog scale of 10, a generalized improvement in pain was also significant $(\mathrm{P}<0.01)$, which associated with percent amelioration $\left(r^{2}=0.65\right)$ [158]. These results further implicate the efficacy of electrotherapy in neuropathic pain management, as a non-pharmacological pain remedy that can be utilized along with analgesics [158]. Long-term benefits may be provided by the electrotherapy treatment, as the average treatment period was $1.7 \pm 0.3$ years [158].

- Twenty-six patients with peripheral neuropathy were administered amitriptyline alone [159]. Four weeks following amitriptyline administration, patients that did not respond to or only partially responded to amitriptyline administration $(n=23)$, were randomly treated with electrotherapy or as controls (sham treatment) [159]. In 85\% of electrotherapeutic patients there was symptomatic improvement, and the level of pain score reduction was significantly better for electrotherapy patients than in the sham patient group $(\mathrm{P}<0.03)$ [159].

- Blum et al. investigated the efficacy of an electrotherapeutic device utilized for the treatment of persistent pain and inflammation, in patients with injuries of the back or lower or upper extremities [160]. The patients reviewed, despite having undergone conventional therapies still experienced at minimum moderate pain [160]. A systematic survey was conducted for these patients two to six weeks into electrotherapy treatment; metrics for improvement included pain relief of at least $25 \%$, function improvement and/or a reduction in the requirement of medications [160]. Over $60 \%$ of all patients experienced at least $25 \%$ improvement in pain relief [160]. More than 50\% of all patients were capable of performing a new activity and experienced function improvement. Furthermore, over 40\% reduced or eliminated pain medication use [160]. The success of electrotherapy did not associate with any of the previously used conventional therapies, for any anatomic subgroup (lower extremity, upper extremity or back pain groups) [160]. Furthermore, for each subgroup, the percentage of patients reporting improvements in more than one metric of improvement was significantly greater than the placebo therapy expected response $(\mathrm{P}<0.001)$ [160]. The results of this study suggest the importance of electrotherapy in the treatment of persistent neuropathic pain and inflammation of soft tissue [160].

- Blum et al., in a follow-up study on the efficacy of an electrotherapy device, conducted an observational, cross-sectional study of patients utilizing the electrotherapy device for persistent soft-tissue ailments and neuropathic pain relief $(n=6774$; male $=3367$, female $=3406$ and 1 patient did not report sex; aged $45.28 \pm$ $10.08 \mathrm{y}$; age range, 18 - $65 \mathrm{y}$ ); a 10-item computer administered survey was utilized which determined patient pain relief of at least $25 \%$, function improvement and/or reduction in the requirement of pain medica- 
tions [161]. Subjects, on average, underwent $87.35 \pm 1.39$ days of self-administered electrotherapy before completing the survey [161]. The survey determined that, reportedly, $65 \%$ of subjects reduced or eliminated pain medication use; $78 \%$ of patients experienced at least $25 \%$ improvement in pain relief; and $79 \%$ of patients were capable of performing a new activity and experienced function improvement [161]. The results of this study and magnitude of this cross-sectional analysis further implicate the importance and benefits of electrotherapy in the treatment of persistent neuropathic pain and inflammation of soft tissue and as a non-pharmacologic alternative to conventional treatments [161].

- In animals electrical stimulation by an electrotherapy device reduced thermal hypersensitivity with longer withdrawal latencies after daily application of electrical stimulation to a partial ligated sciatic nerve (model of neuropathic pain), thus indicating its potential utility as a treatment modality for symptoms associated with this type of neuropathic pain [162].

In a meta-analysis a post-hoc analysis of six published studies related to the pain relief, pain medication reduction and increased functionality obtained with the utilization of the Electrotherapy device was reviewed. 8065 human participants (M-3,902; F-4,163) and twenty male rats were reviewed [163]. In these studies selfreports for both pain medication reduction and increased functionality was obtained by utilizing a cross sectional survey and pain relief instruments involved cross sectional surveys based on visual analog scale (VAS) [163]. A review of the literature revealed that the clinical studies were Random Controlled Trials (RCT) with Placebo Control but there were no prospective outcome studies [163]. The mean weighted effect size [n $=9]\left(M_{E S}\right)$ was 0.61 , the estimated ES variance $\left(M_{E S} V\right)$ was 0.000002 with a $95 \%$ confidence interval (CI) [0.608 - 0.612] [163]. The Electrotherapy device decreased pain across various chronic soft tissue inflammation and neuropathic painful conditions [163]. The mean weighted effect size $\left(M_{E S}\right)$ was 0.59 , the estimated ES variance $\left(M_{E S} V\right)$ was 0.00003 with a $95 \%$ CI [0.580 - 0.600] [163]. The Electrotherapy device decreased pain medication across various chronic soft tissue inflammation and neuropathic painful conditions [163]. The mean weighted effect size $\left(M_{E S}\right)$ was 0.56 , the estimated ES variance $\left(M_{E S} V\right)$ was 0.000013 with $95 \%$ CI [0.553 - 0.567]. The Electrotherapy device increased functionality across various chronic soft tissue inflammation and neuropathic painful conditions [163]. The mean weighted effect size $\left(M_{E S}\right)$ was 0.70, the estimated ES variance $\left(M_{E S} V\right)$ was 0.00002 with a 95\% CI [0.691 - 0.709] [163]. Significant variability $(\mathrm{P}<0.00001)$ was determined by a chi-squared test for homogenous effect sizes, which demonstrated a significant effect size for improved function relative to both reduction in use of pain medication and pain relief [163]. There was no evidence of any adverse effects of Electrotherapy utilization [163]. The findings of this meta-analysis study suggest two conditions [163]. First, they point to a moderate-to-strong effect by means of Electrotherapy device to reduce pain, reduce pain medication and increase functionality, whereby, increased functionality provides the most robust effect [163]. Second, findings suggest that these effects are consistently beneficial to the injured patient [163]. Thus, this meta-analysis favors the reliability of an effective treatment of the Electrotherapy procedure mandating additional RTC perspective studies [163].

\subsection{Proposed Reward Deficiency System Solution}

The program involves the collection of salvia and the DNA is extracted for subsequent analysis of the following genes: Dopamine D1-D5 receptors (DRD); Serotonin 5-Ht2a receptor (5t2a), and the COMT enzyme; MOA; PENK, MOR; GABAR3. Other reward circuitry genes are optionally included. Based on the results of this genotyping the subject is categorized according to the number of polymorphisms that have been associated with high risk RDS.

If an individual is already addicted to an opioid pain medication, that individual will be placed on the KB220Z nutraceutical. In this scenario, the individual will receive ten treatments consisting of a prescription intramuscular injection (IM), an intra-rectal bolus (IR) and a flavored oral suspension drink. Both the IM and IR injections will be delivered under the supervision of a physician trained and certified in the Reward Deficiency System Solution program. Understanding the chronic nature of a predisposition to addictive behavior the individual will receive additional support such as a maintenance program involving the KB220Z nutraceutical for a 3 - 12-month period. Patients that are not addicted to pain medication or other psychoactive substance including alcohol will not be intensively treated but will participate in lesser prescription KB220Z program.

In addition any DNA-identified high RDS risk individual will be immediately set-up with an Electrotherapy device and in-service by a trained representative. In this scenario if a patient possesses a risk genotype he/she will not be placed on a typical pain medication. The duration of use of the Electrotherapy device is dependent 
upon the severity and cessation of the pain condition.

\subsection{Our Hypothesis}

Based on consensus of the literature, we hypothesize that individuals genetically predisposed to SUD may have increased vulnerability to accidents which are work related. We further hypothesize that this vulnerable population will possess brain circuitry and reward cascade polymorphisms, such as: Dopaminergic (i.e. DRD2 receptor genes); Serotonergic (i.e. 5-HTT2 receptor genes); Endorphinergic (i.e. pre-enkephalin genes); Gabergic (i.e. $\mathrm{GABA}_{\mathrm{A}}$ receptor genes); Neurotransmitter Metabolizing genes (i.e. MAO and COMT genes) as well as others. Moreover, analgesic addiction as well as "pseudoaddiction" must be treated in order to improve pain control and its management. Based on medical evidence, we propose that a non-pharmacological alternative to pain relief, in high risk addiction prone individuals, is the Electrotherapeutic Device and Program. We further propose based on clinical evidence that the KB220Z complex; a nutraceutical designed to release DA at the NAc, would reduce craving behavior, in genetically programmed individuals. By utilizing both the Electrotherapy device and the KB220Z Complex, in DNA analyzed injured workers, a reduction in analgesic addiction (genuine or pseudo) would lead to improved health and quicker return to work.

We also hypothesize that this novel approach (identifying genetically programmed RDS candidates by utilizing DNA analysis and customization of the KB220Z Complex targeted to polymorphisms as well psychologically defined RDS parameters) to treat both global pain and addiction will significantly impact spending and costs related to injuries in the workforce.

\section{Conclusion}

Being cognizant that many more studies are required in terms of our proposal as well understanding many negative reports on certain gene associations regarding RDS, we are still encouraged. Effective management of chronic pain, especially in high addiction prone individuals in the workforce, is possible in spite of being particularly elusive. A series of factors can encumber pain assessment and management, including analgesia addiction, pharmacogenomic response to pain medications, and genetic inherited factors involving gene polymorphisms. Research is required to test these stipulated hypotheses related to genetic proneness to not only addiction but to proneness to accidents in the workplace; reduction of craving behavior by utilization of a natural dopamine D2 agonist like the KB220Z Complex, and the pharmacologic free electrotherapy approach to reduce pain without causing analgesia addiction thereby eliminating elusiveness and achieving attainable effective pain management and quick return to work for potentially millions. Continued research on GARS associations with paper pencil psycho-social tests for severity like the Addiction Severity Index (ASI) and American Society of Addiction Medicine (ASAM) dimensions are underway. We are further proposing that our best chance at prevention is to develop mandates to genotype our children earlier enough utilizing the GARS so that if needed prevention strategies embracing more natural alternatives than addictive stimulants (e.g. ADHD treatments) should translate to reduced RDS behaviors in our precious young members of society with the help of the 12-step program [164] [165].

\section{Acknowledgements}

This work was supported Reward Deficiency Solution System, LLC. Del Mar, California, Path Foundation, NY, New York through a grant from LifeExtension Foundation, Ft. Lauderdale, Florida. Support to Marlene OscarBerman comes from NIAA grants R01-AA07112 and KD5-AA00219, and the Medical Research Services of the VA.

\section{Conflict of Interest}

Kenneth Blum, and Roger L. Waite are stock holders of Reward Deficiency Solution, LLC. Kenneth Blum is a stock holder of IGENE, LLC., distributor of nutrigenomic patents including the Genetic Addiction Risk Score (GARS) — both Drs Blum and Waite are members of KenBER LLC—having patent rights for nutrigenomic solutions to Reward Deficiency Syndrome (RDS). Both Thomas Simpatico and Kenneth Blum are on the Scientific Advisory Board of Dominion Diagnostics. There are no other conflicts of interest to declare. 


\section{References}

[1] Office of Applied Studies (2009) Substance Abuse and Mental Health Statistics from SAMHSA’s Office of Applied Studies (OAS). http://www.oas.samhsa.gov/data.cfm

[2] Substance Abuse and Mental Health Services Administration Center for Substance Abuse Prevention (2008) Substance Abuse Prevention Dollars and Cents: A Cost Benefit Analysis. US Department of Health and Human Services. (SMA) 07-4298, Washington DC.

[3] Office of National Drug Control Policy (2012) What America’s Users Spend on Illegal Drugs, 2000-2006. Executive Office of the President, Washington DC.

[4] Substance Abuse and Mental Health Services Administration (2004) Overview of Findings from the 2003 National Survey on Drug Use and Health (Office of Applied Studies, NSDUH Series H-24, DHHS Publication No. SMA 04-3963). Rockville.

[5] Wickizer, T.M. (2013) State-Level Estimates of the Economic Costs of Alcohol and Drug Abuse. Journal of Health Care Finance, 39, 71-84.

[6] Matano, R.A., Wanat, S.F., Westrup, D., Koopman, C. and Whitsell, S.D. (2002) Prevalence of Alcohol and Drug Use in a Highly Educated Workforce. Journal of Behavioral Health Services \& Research, 29, 30-44. http://dx.doi.org/10.1007/BF02287830

[7] Boden, L.I. (2006) Occupational Injury and Illness Meet the Labor Market. Annals of the New York Academy of Sciences, 1076, 858-870. http://dx.doi.org/10.1196/annals.1371.011

[8] Wetmorland, M.G. and Buys, N. (2004) A Comparison of Disability Management Practices in Australian and Canadian Workplaces. Work, 23, 31-41.

[9] Melhorn, J.M. (2001) Occupational Orthopaedics in This Millennium. Clinical Orthopaedics \& Related Research, 385, 23-35.

[10] Khan, J., Gerdtham, U.G. and Jansson, B. (2004) Effects of Macroeconomic Trends on Social Security Spending Due to Sickness and Disability. American Journal of Public Health, 94, 2004-2009. http://dx.doi.org/10.2105/AJPH.94.11.2004

[11] Yassi, A., Gilbert, M. and Cvitkovich, Y. (2005) Trends in Injuries, Illnesses, and Policies in Canadian Healthcare Workplaces. Canadian Journal of Public Health, 96, 333-339.

[12] Blum, K. with Payne, J. (1991) Alcohol and the Addictive Brain. The Free Press (Simon and Schuster), New York.

[13] Blum, K., Braverman, E.R., Wood, R.C., Gill, J., Li, C., Chen, T.J.H., Taub, M., Montgomery, A.R., Cull, J.G. and Sheridan, P.J. (1996) Increased Prevalence of the Taq1 $A_{1}$ Allele of the Dopamine Receptor Gene in Obesity with Comorbid Substance Use Disorder. Pharmacogenetics, 6, 297-305.

[14] Blum, K., Braverman, E.R., Holder, J.M., Lubar, J.F., Monastra, V.J., Miller, D., et al. (2000) The Reward Deficiency Syndrome: A Biogenetic Model for the Diagnosis and Treatment of Impulsive, Addictive and Compulsive Behaviors. Journal of Psychoactive Drugs, 32, 1-112. (Supplement) http://dx.doi.org/10.1080/02791072.2000.10736099

[15] Di Chiara, G. (1999) Drug Addiction as Dopamine-Dependent Associative Learning Disorder. European Journal of Pharmacology, 375, 13-30. http://dx.doi.org/10.1016/S0014-2999(99)00372-6

[16] Di Chiara, G. (2002) Nucleus Accumbens Shell and Core Dopamine: Differential Role in Behavior and Addiction. Behavioural Brain Research, 137, 75-114.

[17] Di Chiara, G., Tanda, G., Bassare, V., Pontieri, F., Acquas, E., Fenu, S., Cadoni, C. and Carboni, E. (1999) Drug Addiction as a Disorder of Associative Learning, Role of Nucleus Accumbens Shell/Extended Amygdala Dopamine. Annals of the New York Academy of Sciences, 877, 461-485. http://dx.doi.org/10.1111/j.1749-6632.1999.tb09283.x

[18] Koob, G.F. (2000) Neurobiology of Addiction: Toward the Development of New Therapies. Annals of the New York Academy of Sciences, 909, 170-185. http://dx.doi.org/10.1111/j.1749-6632.2000.tb06682.x

[19] Koob, G.F. (2003) Alcoholism: Allostasis and Beyond. Alcoholism: Clinical and Experimental Research, 27, $232-243$. http://dx.doi.org/10.1097/01.ALC.0000057122.36127.C2

[20] Koob, G.F. and Le Moal, M. (2001) Drug Addiction, Dysregulation of Reward, and Allostasis. Neuropsychopharmacology, 24, 97-129. http://dx.doi.org/10.1016/S0893-133X(00)00195-0

[21] Noble, E.P., Blum, K., Ritchie, T., Montgomery, A. and Sheridan, P. (1991) Allelic Association of the D2 Dopamine Receptor Gene with Receptor-Binding Characteristics. JAMA Psychiatry, 48, 648-654. http://dx.doi.org/10.1001/archpsyc.1991.01810310066012

[22] Volkow, N.D., Chang, L., Wang, G.J., Fowler, J.S., Ding, Y.S., Sedler, M., Logan, J., Franceschi, D., Gatley, J., Hitzemann, R., Gifford, A., Wong, C. and Pappas, N. (2001) Low Level of Brain Dopamine D2 Receptors in Methamphetamine Abusers: Association with Metabolism in the Orbitofrontal Cortex. American Journal of Psychiatry, 158, 377-382. http://dx.doi.org/10.1176/appi.ajp.158.3.377 
[23] Wightman, R.M. and Robinson, D.L. (2002) Transient Changes in Mesolimbic Dopamine and Their Association with "Reward”. Journal of Neurochemistry, 82, 721-735. http://dx.doi.org/10.1046/j.1471-4159.2002.01005.x

[24] Blum, K. and Kozlowski, G.P. (1990) Ethanol and Neuromodulator Interactions: A Cascade Model of Reward. In: Ollat, H., Parvez, S. and Parvez, H., Eds., Alcohol and Behavior, VSP Press, Utrecht, 131-149.

[25] Gessa, G.L., Mutoni, F., Coller, M., Vargin, L. and Mercer, G. (1985) Low Doses of Ethanol Activate Dopaminergic Neurons in the Ventral Tegmental Area. Brain Research, 348, 201-203. http://dx.doi.org/10.1016/0006-8993(85)90381-6

[26] Yadid, G., Pacak, K., Kopin, I.J. and Goldstein, D.S. (1994) Endogenous Serotonin Stimulates Striatal Dopamine Release in Conscious Rats. Journal of Pharmacology and Experimental Therapeutics, 270, 1158-1165.

[27] Parsons, L.H., Weiss, F. and Koob, G.F. (1996) Serotonin 1b Receptor Stimulation Enhances Dopamine-Mediated Reinforcement. Psychopharmacology, 128, 150-160.

[28] Hallbus, M., Magnusson, T. and Magnusson, O. (1997) Influence of 5-HT $1 \mathrm{~B} / 1 \mathrm{D}$ Receptors on Dopamine Release in the Guinea Pig Nucleus Accumbens: A Microdialysis Study. Neuroscience Letters, 225, 57-60. http://dx.doi.org/10.1016/S0304-3940(97)00178-X

[29] Dick, D.M., Bierut, L., Hinrichs, A., Fox, L., Bucholz, K.K., Kramer, J., Kuperman, S., Hesselbrock, V., Schuckit, M., Almasy, L., Tischfield, J., Porjesz, B., Begleiter, H., Nurnberger Jr., J., Xuei, X., Edenberg, H.J. and Foroud, T. (2006) The Role of GABRA2 in Risk for Conduct Disorder and Alcohol and Drug Dependence across Developmental Stages. Behavior Genetics, 36, 577-590. http://dx.doi.org/10.1007/s10519-005-9041-8

[30] Adler, C.M., Elman, I., Weisenfield, N., Kestler, L., Pickar, D. and Breier, A. (2000) Effects of Acute Metabolic Stress on Striatal Dopamine Release in Healthy Volunteers. Neuropsychopharmacology, 22, 545-550. http://dx.doi.org/10.1016/S0893-133X(99)00153-0

[31] Kelley, A.E. and Berridge, K.C. (2002) The Neuroscience of Natural Rewards: Relevance to Addictive Drugs. Journal of Neuroscience, 22, 3306-3311.

[32] Robbins, T.W. and Everitt, B.J. (1996) Neurobehavioural Mechanisms of Reward and Motivation. Current Opinion in Neurobiology, 6, 228-236. http://dx.doi.org/10.1016/S0959-4388(96)80077-8

[33] Hall, R.D., Bloom, F.E. and Olds, J. (1977) Neuronal and Neurochemical Substrates of Reinforcement. Neurosciences Research Program Bulletin, 15, 131-314.

[34] Comings, D.E., Comings, B.G., Muhleman, D., Dietz, G., Shahbahrami, B., Tast, D., Knell, E., Kocsis, P., Baumgarten, R., Kovacs, B.W., Levy, D.L., Smith, M., Kane, J.M., Lieberman, A., Klein, D.N., Macmurray, J., Tosk, J., Sverd, J., Gysin, R. and Flanagan, S. (1991) The Dopamine D2 Receptor Locus as a Modifying Gene in Neuropsychiatric Disorders. JAMA, 266, 1793-1800. http://dx.doi.org/10.1001/jama.1991.03470130073032

[35] Koob, G.F. (1992) Drug Abuse: Anatomy, Pharmacology and Function of Reward Pathways. Trends in Pharmacological Sciences, 13, 177-184. http://dx.doi.org/10.1016/0165-6147(92)90060-J

[36] Nakajima, S. (1989) Subtypes of Dopamine Receptors Involved in the Mechanism of Reinforcement. Neuroscience \& Biobehavioral Reviews, 13, 123-128. http://dx.doi.org/10.1016/S0149-7634(89)80020-X

[37] Blum, K., Sheridan, P.J., Wood, R.C., Braverman, E.R., Chen, T.J. and Comings, D.E. (1996) The D2 Dopamine Receptor Gene as a Determinant of Reward Deficiency Syndrome. Journal of the Royal Society of Medicine, 89, 396-400.

[38] Miller, W.B., Pasta, D.J., Macmurray, J., Chiu, C., Wu, H. and Comings, D.E. (1999) Dopamine Receptor Genes Are Associated with Age at First Sexual Intercourse. Journal of Biosocial Science, 31, 43-54. http://dx.doi.org/10.1017/S0021932099000437

[39] Comings, D.E., Muhleman, D. and Gysin, R. (1996) Dopamine D2 Receptor (DRD2) Gene and Susceptibility to Posttraumatic Stress Disorder: A Study and Replication. Biological Psychiatry, 40, 368-372. http://dx.doi.org/10.1016/0006-3223(95)00519-6

[40] Kreek, M.J. and Koob, G.F. (1998) Drug Dependence: Stress and Dysregulation of Brain Reward Pathways. Drug and Alcohol Dependence, 51, 23-47. http://dx.doi.org/10.1016/S0376-8716(98)00064-7

[41] Pani, L., Porcella, A. and Gessa, G.L. (2000) The Role of Stress in the Pathophysiology of the Dopaminergic System. Molecular Psychiatry, 5, 14-21. http://dx.doi.org/10.1038/sj.mp.4000589

[42] Robinson, T.E. and Berridge, K.C. (1989) The Neural Basis of Drug Craving an Incentive-Sensitization Theory of Addiction. Brain Research Reviews, 18, 247-291. http://dx.doi.org/10.1016/0165-0173(93)90013-P

[43] Gardner, E.L. (1997) Brain Reward Mechanisms. In: Lowenson, J.H., Ruiz, P., Millman, R.B. and Langrod, J.G., Eds., Substance Abuse: A Comprehensive Textbook, 51-58.

[44] Blum, K., Cull, J.G., Braverman, E.R. and Comings, D.E. (1996) Reward Deficiency Syndrome. The American Scientist, 84, 132-145.

[45] Comings, D.E. and Blum, K. (2000) Reward Deficiency Syndrome: Genetic Aspects of Behavioral Disorders. Progress 
in Brain Research, 126, 325-341. http://dx.doi.org/10.1016/S0079-6123(00)26022-6

[46] Volkow, N.D., Fowler, J.S. and Wang, G.J. (2002) Role of Dopamine in Drug Reinforcement and Addiction in Humans: Results from Imaging Studies. Behavioural Pharmacology, 13, 355-366. http://dx.doi.org/10.1097/00008877-200209000-00008

[47] Di Chiara, G. and Impereto, A. (1988) Drugs Abused by Humans Preferentially Increase Synaptic Dopamine Concentrations in the Mesolimbic Systems of Freely Moving Rats. Proceedings of the National Academy of Sciences of the United States of America, 85, 5274-5278.

[48] Blum, K., Noble, E.P., Sheridan, P.J., Montgomery, A., Ritchie, T., Jagadeeswaran, P., Nogami, H., Briggs, A.H. and Cohn, J.B. (1990) Allelic Association of Human Dopamine $\mathrm{D}_{2}$ Receptor Gene in Alcoholism. Journal of the American Medical Association, 263, 2055-2060. http://dx.doi.org/10.1001/jama.1990.03440150063027

[49] Blum, K., Noble, E.P., Sheridan, P.J., Finley, O., Montgomery, A., Ritchie, T., Ozkaragoz, T., Fitch, R.J., Sadlack, F., Sheffield, D., et al. (1991) Association of the A1 Allele of the D2 Dopamine Receptor Gene with Severe Alcoholism. Alcohol, 8, 409-416. http://dx.doi.org/10.1016/0741-8329(91)90693-Q

[50] Blum, K., Noble, E.P., Sheridan, P.J., Montgomery, A., Ritchie, T., Ozkaragoz, T., Fitch, R.J., Wood, R., Finley, O. and Sadlack, F. (1993) Genetic Predisposition in Alcoholism: Association of the D2 Dopamine Receptor TaqI B1 RFLP with Severe Alcoholics. Alcohol, 10, 59-67. http://dx.doi.org/10.1016/0741-8329(93)90054-R

[51] Hietata, J., West, C., Syvalahti, E., Nagren, K., Lehikoinen, P., Sonninen, P. and Ruotsalainen, U. (1994) Striatal $D_{2}$ Dopamine Receptor Binding Characteristics in Vivo in Patients with Alcohol Dependence. Psychopharmacology, 116, 285-290. http://dx.doi.org/10.1007/BF02245330

[52] Xu, K., Lichterman, D., Kipsky, R.H., Franke, P., Liu, X., Hu, Y., et al. (2004) Association of Specific Haplotypes of D2 Dopamine Receptor Gene with Vulnerability to Heroin Dependence in Distinct Populations. JAMA Psychiatry, 61, 597-606. http://dx.doi.org/10.1001/archpsyc.61.6.597

[53] Volkow, N.D., Wang, G.J., Fowler, J.S., Logan, J., Hitzemann, R., Ding, Y.S., Pappas, N., Shea, C. and Piscani, K. (1996) Decreases in Dopamine Receptors but Not in Dopamine Transporters in Alcoholics. Alcoholism: Clinical and Experimental Research, 20, 1594-1598. http://dx.doi.org/10.1111/j.1530-0277.1996.tb05936.x

[54] Myers, R.D. and Robinson, D.E. (1999) M $\mu$ and D2 Receptor Antisense Oligonucleotides Injected in Nucleus Accumbens Suppress High Alcohol Intake in Genetic Drinking HEP Rats. Alcohol, 18, 225-233. http://dx.doi.org/10.1016/S0741-8329(99)00015-4

[55] Thanos, P.K., Volkow, N.D., Freimuth, P., Umegaki, H., Ikari, H., Roth, G., Ingram, D.K. and Hitzemann, R. (2001) Overexpression of Dopamine D2 Receptor Gene Reduces Alcohol Self-Administration. Journal of Neurochemistry, 78, 1094-1103. http://dx.doi.org/10.1046/j.1471-4159.2001.00492.x

[56] Gilman, S., Koeppe, R.A., Adams, K.M., Junck, L., Kluin, K.J., Johnson-Greene, D., Martorello, S., Heumann, M. and Bandekar, R. (1998) Decreased Striatal Monoaminergic Terminals in Severe Chronic Alcoholism Demonstrated With ${ }^{11}$ C-Dihydrotetrabenazine and Positron Emission Tomography. Annals of Neurology, 44, 326-333. http://dx.doi.org/10.1002/ana.410440307

[57] Comings, D.E., Wu, S., Chiu, C., Ring, R.H, Gade, R., Ahn, C., Macmurray, J.P., Dietz, G. and Muhlman, D. (1996) Polygenic Inheritance of Tourette Syndrome, Stuttering, Attention Deficit Hyperactivity, Conduct, and Oppositional Defiant Disorder: The Additive and Subtractive Effect of the Three Dopaminergic Genes DRD2, DBH, and DAT1. American Journal of Medical Genetics, 67, 264-288.

http://dx.doi.org/10.1002/(SICI)1096-8628(19960531)67:3<264::AID-AJMG4>3.0.CO;2-N

[58] Comings, D.E., Dietz, G., Johnson, J.P. and MacMurray, J.P. (1999) Association of the Enkephalinase Gene with Low Amplitude P300 Waves. Neuroreport, 10, 2283-2285. http://dx.doi.org/10.1097/00001756-199908020-00011

[59] Comings, D.E., Muhlman, D., Ahn, C., Gysin, R. and Flanagan, S.D. (1994) The Dopamine D2 Receptor Gene: A Genetic Risk Factor in Substance Abuse. Drug and Alcohol Dependence, 34, 175-180. http://dx.doi.org/10.1016/0376-8716(94)90154-6

[60] Comings, D.E., Gade-Andavolu, R., Gonzalez, N., Wu, S., Muhleman, D., Chen, C., Koh, P., Farwell, K., Blake, H., Dietz, G., Macmurray, J.P., Lesieur, H.R., Rugle, L.J. and Rosenthal, R.J. (2001) The Additive Effect of Neurotransmitter Genes in Pathological Gambling. Clinical Genetics, 60, 107-116. http://dx.doi.org/10.1034/j.1399-0004.2001.600204.x

[61] Comings, D., Johnson, P., Dietz, G. and Muhleman, D. (1995) Dopamine D2 Receptor Gene (DRD2) Haplotypes and the Defense Style Questionnaire in Substance Abuse, Tourette Syndrome and Controls. Biological Psychiatry, 37, 798805. http://dx.doi.org/10.1016/0006-3223(94)00222-O

[62] Comings, D.E., Gade-Andavilu, R., Gonzalez, N., Wu, S., Muhlman, D., Blake, H., Chiu, F., Farwell, K., Darakjy, S., Baker, R., Dietz, G., Saucier, G. and Macmurray, J.P. (2000) Multivariate Analysis of Associations of 42 Genes in ADHD, ODD and Conduct Disorder. Clinical Genetics, 58, 31-40. http://dx.doi.org/10.1034/j.1399-0004.2000.580106.x 
[63] Noble, E.P., Gottschalk, L.A., Fallon, J.H., Ritchie, T.L. and Wu, J.C. (1997) D2 Dopamine Receptor Polymorphism and Brain Regional Glucose Metabolism. American Journal of Medical Genetics, 74, 162-166. http://dx.doi.org/10.1002/(SICI)1096-8628(19970418)74:2<162::AID-AJMG9>3.0.CO;2-W

[64] Noble, E.P., Noble, R.E., Ritchie, T., Syndulko, K., Bohlman, M.C., Noble, L.A., Sparkes, R.S. and Grandy, D.K. (1994) D2 Dopamine Receptor Gene and Obesity. International Journal of Eating Disorders, 15, 205-217. http://dx.doi.org/10.1002/1098-108X(199404)15:3<205::AID-EAT2260150303>3.0.CO;2-P

[65] Noble, E.P., Ozkaragoz, T.Z., Ritchie, T., Zhang, X., Bekin, T.R. and Sparkes, R.S. (1998) D2 and D4 Dopamine Receptor Poymorphisms and Personality. American Journal of Medical Genetics, 81, 257-267. http://dx.doi.org/10.1002/(SICI)1096-8628(19980508)81:3<257::AID-AJMG10>3.0.CO;2-E

[66] Noble, E.P., Syndilko, K., Fitch, R.J., Ritchie, T., Bohlman, M.C., Gith, P., Sherifan, P.J., Montgomery, A., Heinzman, C., Sparkes, R.S. and Blum, K. (1994) D2 Dopamine Receptor Taq1 a Alleles in Medically Ill Alcoholic and Nonalcoholic Patients. Alcohol and Alcoholism, 29, 729-744.

[67] Noble, E.P., Zhang, X., Ritchie, T., Lawford, B.R., Grosser, S.C., Young, R.M. and Sparkes, R.S. (1998) D 2 Dopamine Receptor and GABA (A) Receptor Beta3 Subunit Gene Alcoholism. Psychiatry Research, 81, 133-147. http://dx.doi.org/10.1016/S0165-1781(98)00084-5

[68] Noble, E.P. (2003) $\mathrm{D}_{2}$ Dopamine Receptor Gene in Psychiatric and Neurologic Disorders and Its Phenotypes. American Journal of Medical Genetics Part B, 116B, 103-125. http://dx.doi.org/10.1002/ajmg.b.10005

[69] Miller, W.B., Pasta, D.J., Macmurray, J., Chiu, C., Wu, H. and Comings, D.E. (1999) Dopamine Receptor Genes Are Associated with Age at First Sexual Intercourse. Journal of Biosocial Science, 31, 43-54. http://dx.doi.org/10.1017/S0021932099000437

[70] Bau, C.H.D., Almeida, S. and Hutz, M.H. (2000) The Taqi A1 Allele of the Dopamine D2 Receptor Gene and Alcoholism in Brazil: Association and Interaction with Stress and Harm Avoidance on Severity Prediction. American Journal of Medical Genetics, 96, 302-306. http://dx.doi.org/10.1002/1096-8628(20000612)96:3<302::AID-AJMG13>3.0.CO;2-I

[71] Uhl, G., Blum, K., Noble, E. and Smith, S. (1993) Substance Abuse Vulnerability and D2 Receptor Genes. Trends in Neurosciences, 16, 83-88. http://dx.doi.org/10.1016/0166-2236(93)90128-9

[72] Volkow, N.D., Wang, J.G., Beglieter, H., Porjesz, B., Fowler, J.S., Telang, F., Wong, C., Ma, Y., Logan, J., Goldstein, R., Alexoff, D. and Thanos, P.K. (2006) High Levels of Dopamine $\mathrm{D}_{2}$ in Unaffected Members of Alcoholic Families. JAMA Psychiatry, 63, 999-1008. http://dx.doi.org/10.1001/archpsyc.63.9.999

[73] Lesch, K.P. (2005) Genetic Alterations of the Murine Serotonergic Gene Pathway: The Neurodevelopmental Basis of Anxiety. Handbook of Experimental Pharmacology, 169, 71-112. http://dx.doi.org/10.1007/3-540-28082-0_3

[74] Nellissery, M., Feinn, R.S., Covault, J., Gelernter, J., Anton, R.F., Pettinati, H., Moak, D., Mueller, T. and Kranzler, H.R. (2003) Alleles of a Functional Serotonin Transporter Promoter Polymorphism Are Associated with Major Depression in Alcoholics. Alcoholism: Clinical and Experimental Research, 27, 1402-1408. http://dx.doi.org/10.1097/01.ALC.0000085588.11073.BB

[75] Crabbe, J.C., Phillips, T.J., Harris, R.A., Arends, M.A. and Koob, G.F. (2006) Alcohol-Related Genes: Contributions from Studies with Genetically Engineered Mice. Addiction Biology, 11, 195-269. http://dx.doi.org/10.1111/j.1369-1600.2006.00038.x

[76] Edenberg, H.J. and Kranzler, H.R. (2005) The Contribution of Genetics to Addiction Therapy Approaches. Pharmacology \& Therapeutics, 108, 86-93. http://dx.doi.org/10.1016/j.pharmthera.2005.06.011

[77] Sinha, R., Cloninger, C.R. and Parsian, A. (2003) Linkage Disequilibrium and Haplotype Analysis between Serotonin Receptor 1B Gene Variations and Subtypes of Alcoholism. American Journal of Medical Genetics Part B: Neuropsychiatric Genetics, 121, 83-88. http://dx.doi.org/10.1002/ajmg.b.20064

[78] Hill, E.M., Stoltenberg, S.F., Bullard, K.H., Li, S., Zucker, R.A. and Burmeister, M. (2002) Antisocial Alcoholism and Serotonin-Related Polymorphisms: Association Tests. Psychiatric Genetics, 12, 143-153. http://dx.doi.org/10.1097/00041444-200209000-00005

[79] Sun, H.F., Chang, Y.T., Fann, C.S., Chang, C.J., Chen, Y.H., Hsu, Y.P., Yu, W.Y. and Cheng, A.T. (2002) Association Study of Novel Human Serotonin 5-HT(1B) Polymorphisms with Alcohol Dependence in Taiwanese Han. Biological Psychiatry, 51, 896-901. http://dx.doi.org/10.1016/S0006-3223(01)01366-X

[80] Kranzler, H.R., Hernandez-Avila, C.A. and Gelernter, J. (2002) Polymorphism of the 5-HT1B Receptor Gene (HTR1B): Strong Within-Locus Linkage Disequilibrium without Association to Antisocial Substance Dependence. Neuropsychopharmacology, 26, 115-122. http://dx.doi.org/10.1016/S0893-133X(01)00283-4

[81] Parsian, A. and Cloninger, C.R. (2001) Serotonergic Pathway Genes and Subtypes of Alcoholism: Association Studies. Psychiatric Genetics, 11, 89-94. http://dx.doi.org/10.1097/00041444-200106000-00006

[82] Fehr, C., Schleicher, A., Szegedi, A., Anghelescu, I., Klawe, C., Hiemke, C. and Dahmen, N. (2001) Serotonergic Po- 
lymorphisms in Patients Suffering from Alcoholism, Anxiety Disorders and Narcolepsy. Progress in Neuro-Psychopharmacology and Biological Psychiatry, 25, 965-982. http://dx.doi.org/10.1016/S0278-5846(01)00171-3

[83] Preuss, U.W., Koller, G., Bondy, B., Bahlmann, M. and Soyka, M. (2001) Impulsive Traits and 5-HT2A Receptor Promoter Polymorphism in Alcohol Dependents: Possible Association but No Influence of Personality Disorders. Neuropsychobiology, 43, 186-191. http://dx.doi.org/10.1159/000054888

[84] Fehr, C., Szegedi, A., Anghelescu, I., Klawe, C., Hiemke, C. and Dahmen, N. (2000) Sex Differences in Allelic Frequencies of the 5-HT2C Cys23Ser Polymorphism in Psychiatric Patients and Healthy Volunteers: Findings from Anassociation Study. Psychiatric Genetics, 10, 59-65. http://dx.doi.org/10.1097/00041444-200010020-00001

[85] Comings, D.E., Gade, R., Muhleman, D., Chiu, C., Wu, S., To, M., Spence, M., Dietz, G., Winn-Deen, E., Rosenthal, R.J., Lesieur, H.R., Rugle, L., Sverd, J., Ferry, L., Johnson, J.P. and Macmurray, J.P. (1996) Exon and Intron Variants in the Human Tryptophan 2,3-Dioxygenase Gene: Potential Association with Tourette Syndrome, Substance Abuse and Other Disorders. Pharmacogenetics, 6, 307-318. http://dx.doi.org/10.1097/00008571-199608000-00004

[86] Lam, S., Shen, Y., Nguyen, T., Messier, T.L., Brann, M., Comings, D., George, S.R. and O’Dowd, B.F. (1996) A Serotonin Receptor Gene (5HT1A) Variant Found in a Tourette's Syndrome Patient. Biochemical and Biophysical Research Communications, 219, 853-858. http://dx.doi.org/10.1006/bbrc.1996.0322

[87] Contini, V., Marques, F.Z., Garcia, C.E., Hutz, M.H. and Bau, C.H. (2006) MAOA-uVNTR Polymorphism in a Brazilian Sample: Further Support for the Association with Impulsive Behaviors and Alcohol Dependence. American Journal of Medical Genetics Part B: Neuropsychiatric Genetics, 141, 305-308. http://dx.doi.org/10.1002/ajmg.b.30290

[88] Eriksson, M., Berggren, U., Blennow, K., Fahlke, C., Mansson, J.E. and Balldin, J. (2000) Alcoholics with the Dopamine Receptor DRD2 A1 Allele Have Lower Platelet Monoamine Oxidase-B Activity than Those with the A2 Allele: A Preliminary Study. Alcohol and Alcoholism, 35, 493-498. http://dx.doi.org/10.1093/alcalc/35.5.493

[89] Schmidt, L.G., Sander, T., Kuhn, S., Smolka, M., Rommelspacher, H., Samochowiec, J. and Lesch, K.P. (2000) Different Allele Distribution of a Regulatory MAOA Gene Promoter Polymorphism in Antisocial and Anxious-Depressive Alcoholics. Journal of Neural Transmission, 107, 681-689. http://dx.doi.org/10.1007/s007020070069

[90] Blum, K., Chen, T.J.H., Meshkin, B., Waite, R.L., Downs, W.B., Blum, S.H., Mengucci, J.F., Arcuri, V., Braverman, E.R. and Paloma, T. (2007) Manipulation of Catechol-O-Methyl Transferase (COMT) Activity to Influence the Attenuation of Substance Seeking Behavior, a Subtype of Reward Deficiency Syndrome (RDS), Is Dependent upon Gene Polymorphisms: A Hypothesis. Medical Hypotheses, 69, 1054-1060.

http://dx.doi.org/10.1016/j.mehy.2006.12.062

[91] Kim, B.N., Hwang, J.W., Shin, M.S., Hong, K.E. and Cho, S.C. (2005) Positive Association between Tourette’s Disorder and Catechol-O-Methyl Transferase Gene in Korean Subjects. Psychiatry Investigation, 2, 85-91.

[92] Long, J.C., Knowler, W.C., Hanson, R.L., Robin, R.W., Urbanek, M., Moore, E., Bennett, P.H. and Goldman, D. (1998) Evidence for Genetic Linkage to Alcohol Dependence on Chromosomes 4 and 11 from an Autosome-Wide Scan in an American Indian Population. American Journal of Medical Genetics, 81, 216-221. http://dx.doi.org/10.1002/(SICI)1096-8628(19980508)81:3<216::AID-AJMG2>3.0.CO;2-U

[93] Tiihonen, J., Hallikainen, T., Lachman, H., Saito, T., Volavka, J., Kauhanen, J., et al. (1999) Association between the Functional Variant of the Catechol-O-Methlytransferase (COMT) Gene and Type 1 Alcoholism. Molecular Psychiatry, 4, 286-289. http://dx.doi.org/10.1038/sj.mp.4000509

[94] Hosak, L., Libiger, J., Cizek, J., Beranek, M. and Cermakova, E. (2006) The COMT Val158Met Polymorphism Is Associated with Novelty Seeking in Czech Methamphetamine Abusers: Preliminary Results. Neuro Endocrinology Letters, 27, 799-802.

[95] Blum, K., Futterman, S., Wallace, J.E. and Schwertner, H.A. (1977) Naloxone-Induced Inhibition of Ethanol Dependence in Mice. Nature, 265, 49-51. http://dx.doi.org/10.1038/265049a0

[96] Blum, K., Briggs, A.H., Elston, S.F., Delallo, L., Sheridan, P.J. and Sar, M. (1982) Reduced Leucine-EnkephalinLike Immunoreactive Substance in Hamster Basal Ganglia after Long-Term Ethanol Exposure. Science, 216, 14251427.

[97] Hollt, V., Haarmann, I. and Herz, A. (1981) Long-Term Treatment of Rats with Morphine Reduces the Activity of Messenger Ribonucleic Acid Coding for the Beta-Endorphin/ACTH Precursor in the Intermediate Pituitary. Journal of Neurochemistry, 37, 619-626. http://dx.doi.org/10.1111/j.1471-4159.1982.tb12532.x

[98] Genazzani, A.R., Nappi, G., Facchinetti, F., Mazzella, G.L., Parrini, D., Sinforiani, E., Petraglia, F. and Savoldi, F. (1982) Central Deficiency of Beta-Endorphin in Alcohol Addicts. Journal of Clinical Endocrinology \& Metabolism, 55, 583-586. http://dx.doi.org/10.1210/jcem-55-3-583

[99] Blum, K. and Topel, H. (1986) Opioid Peptides and Alcoholism: Genetic Deficiency and Chemical Management. Functional Neurology, 1, 71-83.

[100] Gianouculakis, C. (2004) Endogenous Opioids and Addiction in Alcohol and Other Drugs of Abuse. Current Topics in 
Medicinal Chemistry, 4, 39-50. http://dx.doi.org/10.2174/1568026043451573

[101] Ratsma, J.E., Van Der Stelt, O. and Gunning, W.B. (2002) Neurochemical Markers of Alcoholism Vulnerability in Humans. Alcohol and Alcoholism, 37, 523-533. http://dx.doi.org/10.1093/alcalc/37.6.522

[102] Blum, K., Noble, E.P., Sheridan, P.J., Montgomery, A., Ritchie, T., Ozkaragoz, T., Fitch, R.J., Wood, R., Finley, O. and Sadlack, F. (1993) Genetic Predisposition in Alcoholism: Association of the $\mathrm{D}_{2}$ Dopamine Receptor TaqI B1 RFLP with Severe Alcoholics. Alcohol, 10, 59-67. http://dx.doi.org/10.1016/0741-8329(93)90054-R

[103] Krystal, J.H., D’souza, D.C., Gallinat, J., Driesen, N., Abi-Dargham, A., Petrakis, I., Heinz, A. and Pearlson, G. (2006) The Vulnerability to Alcohol and Substance Abuse in Individuals Diagnosed with Schizophrenia. Neurotoxicity Research, 10, 235-252. http://dx.doi.org/10.1007/BF03033360

[104] Lappalainen, J., Krupitsky, E., Kranzler, H.R., Luo, X., Remizov, M., Pchelina, S., Taraskina, A., Zvartau, E., Rasanen, P., Makikyro, T., Somberg, L.K., Krystal, J.H., Stein, M.B. and Gelernter, J. (2006) Mutation Screen of the GAD2 Gene and Association Study of Alcoholism in Three Populations. American Journal of Medical Genetics Part B: Neuropsychiatric Genetics, 144, 183-192.

[105] Young, R.M., Lawford, B.R., Feeney, G.F., Ritchie, T. and Noble, E.P. (2004) Alcohol-Related Expectancies Are Associated with the D2 Dopamine Receptor and GABAA Receptor Beta3 Subunit Genes. Psychiatry Research, 127, 171-183. http://dx.doi.org/10.1016/j.psychres.2003.11.004

[106] Radel, M., Vallejo, R.L., Iwata, N., Aragon, R., Long, J.C., Virkkunen, M. and Goldman, D. (2005) Haplotype-Based Localization of an Alcohol Dependence Gene to the $5 q 34 \gamma$-Aminobutyric Acid Type A Gene Cluster. JAMA Psychiatry, 62, 47-55. http://dx.doi.org/10.1001/archpsyc.62.1.47

[107] Brady, R.O. (1994) Potential Gene Therapy for Alcoholism. EXS, 71, 383-393.

[108] Blum, K., Wallace, J.E., Trachtenberg, M.C., Delallo, L. and Wallace, J.E. (1987) Enkephalinase Inhibition: Regulation of Ethanol Intake in Genetically Predisposed Mice. Alcohol, 4, 449-456. http://dx.doi.org/10.1016/0741-8329(87)90084-X

[109] Carelli, R.M. (2004) Nucleus Accumbens Cell Firing and Rapid Dopamine Signaling during Goal-Directed Behaviors in Rats. Neuropharmacology, 47, 180-189. http://dx.doi.org/10.1016/j.neuropharm.2004.07.017

[110] Carboni, E., Silvagni, A., Rolando, M.T. and Di Chiara, G. (2000) Stimulation of in Vivo Dopamine Transmission in the Bed Nucleus of Stria Terminalis by Reinforcing Drugs. Journal of Neuroscience, 20, 102.

[111] Blum, K., Elston, S.F., Delallo, L., Briggs, A.H. and Wallace, J.E. (1983) Ethanol Acceptance as a Function of Genotype Amounts of Brain (Met) Enkephalin. Proceedings of the National Academy of Sciences of the United States of America, 80, 6510-6520.

[112] Sinclair, J.D., Le, A.D. and Kiianmaa, K. (1989) The AA and ANA Rat Lines, Selected for Differences in Voluntary Alcohol Consumption. Experientia, 45, 798-805. http://dx.doi.org/10.1007/BF01954055

[113] Strother, W.N., Lumeng, L., Li, T.K. and Mcbride, W.J. (2005) Dopamine and Serotonin Content in Select Brain Regions of Weanling and Adult Alcohol Drinking Rat Lines. Pharmacology Biochemistry and Behavior, 80, $229-237$. http://dx.doi.org/10.1016/j.pbb.2004.11.003

[114] Syvaelahti, E.K., Pohjalainen, T., Korpi, E.R., Pälvimäki, E.P., Ovaska, T., Kuoppamäki, M. and Hietala, J. (1994) Dopamine D2 Receptor Gene Expression in Rat Lines Selected for Differences in Voluntary Alcohol Consumption. Alcoholism: Clinical and Experimental Research, 18, 1029-1031. http://dx.doi.org/10.1111/j.1530-0277.1994.tb00078.x

[115] Mcbride, W.J., Chernet, E., Russell, R.N., Wong, D.T., Guan, X.M., Lumeng, L. and Li, T.K. (1997) Regional CNS Densities of Monoamine Receptors in Alcohol-Naive Alcohol-Preferring P and Nonpreferring NP Rats. Alcohol, 14, 141-148. http://dx.doi.org/10.1016/S0741-8329(96)00117-6

[116] Lawford, B.R., Young, R.M., Rowell, J.A., Qualichefski, J., Fletcher, B.H., Syndulko, K., Ritchie, T. and Noble, E.P. (1995) Bromocriptine in the Treatment of Alcoholics with the D2 Dopamine Receptor A1 Allele. Nature Medicine, 1, 337-341. http://dx.doi.org/10.1038/nm0495-337

[117] Blum, K., Chen, T.J.H., Downs, W.B., Meshkin, B., Blum, S.H., Martinez -Pons, M., Mengucci, J.F., Waite, R.L., Acruri, V., Varshofsiky, M. and Braverman, E.R. (2007) KB220Z (Sg8839), ${ }^{\mathrm{TM}}$ an Amino-Acid Enkephalinase Inhibition Nutraceutical Improves Recovery of Alcoholics, a Subtype of Reward Deficiency Syndrome (RDS). Trends in Applied Sciences Research, 2, 132-138.

[118] Grant, K.E., Chandler, R.M., Castle, A.L. and Ivy, J.L. (1997) Chromium and Exercise Training: Effect on Obese Women. J Am Coll Sports Med, 29, 992-998.

[119] Blum, K., Trachtenberg, M.C., Elliott, C.E., Dingler, M.L., Sexton, R.L., Samuels, A.I. and Cataldie, L. (1989) Enkephalinase Inhibition and Precursor Amino Acid Loading Improves Inpatient Treatment of Alcoholics and Poly-Drug Abusers: A Double Blind Placebo Controlled Study of the Neuronutrient Intervention Adjunct SAAVE. Alcohol, 5, 481-493. http://dx.doi.org/10.1016/0741-8329(88)90087-0 
[120] Brown, R.P., Blum, K. and Trachtenberg, M.C. (1990) Neurodynamics of Relapse Prevention: A Neuronutrient Approach to Outpatient DUI Offenders. Journal of Psychoactive Drugs, 22, 173-187. http://dx.doi.org/10.1080/02791072.1990.10472542

[121] Blum, K., Trachtenberg, M.C. and Ramsey, J. (1988) Improvement of Inpatient Treatment of the Alcoholic as a Function of Neuronutrient Restoration: A Pilot Study. International Journal of Addiction, 123, 991-998.

[122] Blum, K. and Tractenberg, M.C. (1988) Neurogenic Deficits Caused by Alcoholism: Restoration by SAAVE, a Neuronutrient Intervention Adjunct. Journal of Psychoactive Drugs, 20, 297-313. http://dx.doi.org/10.1080/02791072.1988.10472500

[123] Blum, K., Allison, D., Trachtenberg, M.C., Williams, R.W. and Loeblich, L.A. (1988) Reduction of both Drug Hunger and Withdrawal against Advice Rate of Cocaine Abusers in a 30 Day Inpatient Treatment Program by the Neuronutrient Tropamine. Current Therapeutic Research, 43, 1204.

[124] Blum, K., et al. (1990) Neuronutrient Effects on Weight Loss on Carbohydrate Bingeing in an Outpatient Bariatrics Setting. Current Therapeutic Research, 48, 217.

[125] Blum, K., Cull, J.G., Chen, J.H.T., Garcia-Swan, S., Holder, J.M., Wood, R., Braverman, E.R., Bucci, L.R. and Trachtenberg, M.G. (1997) Clinical Evidence for Effectiveness of Phencal ${ }^{\mathrm{TM}}$ in Maintaining Weight Loss in an Open-Label, Controlled, 2-Year Study. Current Therapeutic Research, 58, 745-763. http://dx.doi.org/10.1016/S0011-393X(97)80108-7

[126] Kaats, G.R., Wise, J.A., Blum, K., Morin, R.J., et al. (1992) The Short-Term Therapeutic Efficacy of Treating Obesity with a Plan of Improved Nutrition and Moderate Caloric Restriction. Current Therapeutic Research, 51, 261-274.

[127] Kaats, G.R., Blum, K., Pullin, D., Keith, S.C. and Wood, R. (1998) A Randomized, Double-Masked, Placebo-Controlled Study of the Effects of Chromium Picolinate Supplementation on Body Composition: A Replication and Extension of a Previous Study. Current Therapeutic Research, 59, 379-388. http://dx.doi.org/10.1016/S0011-393X(98)85040-6

[128] Kaats, G.R., Blum, K., Fisher, J.A. and Adelman, J.A. (1996) Effects of Chromium Picolinate Supplementation on Body Composition: A Randomized, Double Masked, Placebo-Controlled Study. Current Therapeutic Research, 57, 747-756. http://dx.doi.org/10.1016/S0011-393X(96)80080-4

[129] Defrance, J.J., Hymel, C., Trachtenberg, M.C., et al. (1997) Enhancement of Attention Processing by Kantrol in Healthy Humans: A Pilot Study. Clinical EEG and Neuroscience, 28, 68-75. http://dx.doi.org/10.1177/155005949702800204

[130] Lachman, H.M., Papolos, D.F., Saito, T., Yu, Y.M., Szumlanski, C.L. and Weinshilboum, R.M. (1996) Human Catechol-O-Methytransferase Pharmacogenetics: Description of a Functional Polymorphism and Its Potential Application to Neuropsychiatric Disorders. Pharmacogenetics, 6, 243-250. http://dx.doi.org/10.1097/00008571-199606000-00007

[131] Tiihonen, J., Hallikainen, T., Lachman, H., Saito, T., Volavka, J., Kauhanen, J., et al. (1999) Association between the Functional Variant of the Catechol-O-Methlytransferase (COMT) Gene and Type 1 Alcoholism. Molecular Psychiatry, 4, 286-289. http://dx.doi.org/10.1038/sj.mp.4000509

[132] Kauhanen, J., Hallikainen, T., Tuomainen, T.P., Koulu, M., Karvonen, M.K., Salonen, J.T. and Tiihonen, J. (2000) Association between the Functional Polymorphism of Catechol-O-Methyltransferase Gene and Alcohol Consumption among Social Drinkers. Alcoholism: Clinical and Experimental Research, 24, 135-139. http://dx.doi.org/10.1111/j.1530-0277.2000.tb04582.x

[133] Hunley, K. and Long, J.C. (2005) Gene Flow across Linguistic Boundaries in Native North American Populations. Proceedings of the National Academy of Sciences of the United States of America, 102, 1312-1317. http://dx.doi.org/10.1073/pnas.0409301102

[134] Stancheva, S.L. and Mosharrof, A. (1987) Effect of the Extract of Rhodiola rosea L. on the Content of the Brain Biogenic Monoamines. Medecine Physiologie Comptes Rendus De l'Academie Bulgare Des Sciences, 40, 85-87.

[135] Wurtman, J.J. and Wurtman, R.J. (1979) Drugs that Enhance Serotonergic Transmission Diminish Elective Carbohydrate Consumption by Rats. Life Sciences, 24, 895-903. http://dx.doi.org/10.1016/0024-3205(79)90339-4

[136] Young, S.N. (1986) The Clinical Psychopharmacology of Tryptophan. In: Wurtman, R.S. and Wurtman, J.J., Eds., Nutrition and the Brain, Vol. 7, Raven Press, New York, 49-88.

[137] Ehrenpreis, S. (1982) D-Phenylalanine and Other Enkephalinase Inhibitors as Pharmacological Agents: Implications for Some Important Therapeutic Application. Subs Alcohol Actions Misuse, 3, 231-239.

[138] Anderson, R.A. (1998) Recent Advances in the Clinical and Biochemical Manifestation of Chromium Deficiency in Human and Animal Nutrition. Journal of Trace Elements in Experimental Medicine, 11, 241-250. http://dx.doi.org/10.1002/(SICI)1520-670X(1998)11:2/3<241::AID-JTRA14>3.0.CO;2-R

[139] Cold, J.A. (1996) Neurecover-SA in the Treatment of Cocaine Withdrawal and Craving: A Pilot Study. Clinical Drug Investigation, 12, 1-7. http://dx.doi.org/10.2165/00044011-199612010-00001 
[140] Chen, T.J., Blum, K., Payte, J.T., Schoolfield, J., Hopper, D., Stanford, M. and Braverman, E.R. (2004) Narcotic Antagonists in Drug Dependence: Pilot Study Showing Enhancement of Compliance with SYN-10, Amino-Acid Precursors and Enkephalinase Inhibition Therapy. Medical Hypotheses, 63, 538-548. http://dx.doi.org/10.1016/j.mehy.2004.02.051

[141] Thanos, P.K., Volkow, N.D., Freimuth, P., Umegaki, H., Ikari, H., Roth, G., Ingram, D.K. and Hitzemann, R. (2001) Overexpression of Dopamine D2 Receptor Gene Reduces Alcohol Self-Administration. Journal of Neurochemistry, 78, 1094-1103. http://dx.doi.org/10.1046/j.1471-4159.2001.00492.x

[142] Ross, J. (2000) Amino-Acid Precursor and Enkephalinase Inhibition Therapy: Evidence for Effectiveness in Treatment of Reward Deficiency Syndrome (RDS), with Particular Emphasis on Eating Disorders. Mol. Psych., 6, S7.

[143] Blum, K., Chen, T.J.H., Downs, W.B., Gordon, C.A., Blum, S., Mengucci, J.F., Braverman, E.R., Arcuri, V., Varshavskiy, M., Deutch, R., Pons, M.M. and Meshkin, B. (2006) Reward Deficiency Syndrome in Obesity: A Preliminary Cross Sectional Open Trial with a Genotrim Variant. Advances in Therapy, 26, 1040-1051.

[144] Savage, S.R. (2002) Assessment for Addiction in Pain-Treatment Settings. Clinical Journal of Pain, 18, S28-S38. http://dx.doi.org/10.1097/00002508-200207001-00004

[145] Sees, K.L. and Clark, H.W. (1993) Opioid Use in the Treatment of Chronic Pain: Assessment of Addiction. Journal of Pain and Symptom Management, 8, 257-264. http://dx.doi.org/10.1016/0885-3924(93)90154-N

[146] Weissman, D.E. and Haddox, J.D. (1989) Opioid Pseudoaddiction—An Iatrogenic Syndrome. Pain, 36, 363-366. http://dx.doi.org/10.1016/0304-3959(89)90097-3

[147] Lusher, J., Elander, J., Bevan, D., Telfer, P. and Burton, B. (2006) Analgesic Addiction and Pseudoaddiction in Painful Chronic Illness. Clinical Journal of Pain, 22, 316-324. http://dx.doi.org/10.1097/01.ajp.0000176360.94644.41

[148] Miller, N.S., Swiney, T. and Barkin, R.L. (2006) Effects of Opioid Prescription Medication Dependence and Detoxification on Pain Perceptions and Self-Reports. American Journal of Therapeutics, 13, 436-444. http://dx.doi.org/10.1097/01.mjt.0000212894.35705.90

[149] Birnbaum, H.G., White, A.G., Reynolds, J.L., Greenberg, P.E., Zhang, M., Vallow, S., Schein, J.R. and Katz, N.P. (2006) Estimated Costs of Prescription Opioid Analgesic Abuse in the United Staes in 2001. Clinical Journal of Pain, 22, 667-676. http://dx.doi.org/10.1097/01.ajp.0000210915.80417.cf

[150] Magnusson, J.E. and Martin, R.V. (2002) Additional Evidence for the Involvement of the Basal Ganglia in Formalin-Induced Nociception: The Role of the Nucleus Accumbens. Brain Research, 942, 128-132. http://dx.doi.org/10.1016/S0006-8993(02)02489-7

[151] Taylor, B.K., Joshi, C. and Uppal, H. (2003) Stimulation of Dopamine D2 Receptors in the Nucleus Accimbens Inhibits Inflammatory Pain. Brain Research, 987, 135-143. http://dx.doi.org/10.1016/S0006-8993(03)03318-3

[152] Hagelberg, N., Forssell, H., Aalto, S., Rinne, J.O., Scheinin, H., Taiminen, T., et al. (2003) Altered Dopamine D2 Receptor Binding in Atypical Facial Pain. Pain, 106, 43-48. http://dx.doi.org/10.1016/S0304-3959(03)00275-6

[153] Blum, K., Chen, T.H.J. and Ross, B.D. (2005) Innate Properties of Electrotherapy Device, a Small Fiber Stimulator Provides the Basis for a Paradigm Shift of Electro-Therapeutic Treatment of Pain with Increased Functional Restoration Associated with Human Neuropathies by Affecting Tissue Circulation. Medical Hypotheses, 64, 1066-1067. http://dx.doi.org/10.1016/j.mehy.2004.11.033

[154] Blum, K., Chen, J.H.T. and Ross, B.D. (2005) Innate Properties of Electrotherapy Device, a Small Fiber Stimulator Provides the Basis for a Paradigm Shift of Electro-Therapeutic Treatment of Pain with Increased Functional Restoration Associated with Human Neuropathies. Townsend Letters, 101-104.

[155] Smith, T.L., Callahan, M.F., Blum, K., Dinubile, N.A., Chen, T.J. and Waite, R.L. (2011) H-Wave® Effects on Blood Flow and Angiogenesis in Longitudinal Studies in Rats. Journal of Surgical Orthopaedic Advances, 20, 255-259.

[156] Smith, T.L., Blum, K., Callahan, M.F., Dinubile, N.A., Chen, T.J. and Waite, R.L. (2009) Electrotherapy Induces Arteriolar Vasodilation in Rat Striated Muscle via Nitric Oxide-Mediated Mechanisms. Journal of Orthopaedic Research, 27, 1248-1251. http://dx.doi.org/10.1002/jor.20851

[157] Tsang, B.K., Tajkaushi, K. and Eichhorn, J.H. (1998) Electrical Stimulation Reduces Symptoms of Thermal Hypersensitivity from Injury of Sciatic Partial Ligation in Rats. Anesthesia \& Analgesia, 86, S1-S551. http://dx.doi.org/10.1097/00000539-199802001-00001

[158] Kumar, D. and Marshall, H.J. (1997) Diabetes Peripheral Neuropathy: Amelioration of Pain with Transcutaneous Electrostimulation. Diabetes Care, 20, 1702-1705. http://dx.doi.org/10.2337/diacare.20.11.1702

[159] Kumar, D., Alvaro, M.S., Julka, I.S. and Marshall, H.J. (1998) Diabetic Peripheral Neuropathy: Effectiveness of Electrotherapy and Amitriptyline for Symptomatic Relief. Diabetes Care, 21, 1322-1325. http://dx.doi.org/10.2337/diacare.21.8.1322

[160] Julka, I.S., Alvaro, M. and Kumar, D. (1998) Beneficial Effects of Electrical Stimulation on Neuropathic Symptoms in Diabetes Patients. Journal of Foot and Ankle Surgery, 37, 191-194. http://dx.doi.org/10.1016/S1067-2516(98)80109-9 
[161] Blum, K., Dinubulie, N., Chen, T.J.H., Waite, R.L., Schoolfield, J., Martinez-Pons, M., Callahan, M.F., Smith, T.L., Mengucci, J., Blum, S.H. and Meshkin, B. (2006) H-Wave, a Nonpharmacologic Alternative for the Treatment of Patients with Chronic Soft Tissue Inflammation and Neuropathic Pain: A Preliminary Statistical Outcome Study. Advances in Therapy, 23, 446-455. http://dx.doi.org/10.1007/BF02850166

[162] Blum, K., Martinez-Pons, M., Dinubulie, N.A., Chen, T.J.H., Waite, R.L., Schoolfield, J., Blum, S.H., Mengucci, J.F., Downs, W.B. and Meshkin, B. (2006) The H-Wave ${ }^{\circledR}$ Small Muscle Fiber Stimulator, a Nonpharmacologic Alternative for the Treatment of Chronic Soft-Tissue Injury and Neuropathic Pain: An Extended Population Observational Study. Advances in Therapy, 23, 739-749. http://dx.doi.org/10.1007/BF02850314

[163] Blum, K., Chen, A.L., Chen, T.J., Prihoda, T.J., Schoolfield, J., Dinubile, N., Waite, R.L., Arcuri, V., Kerner, M., Braverman, E.R., Rhoades, P. and Tung, H. (2008) The H-Wave ${ }^{\circledR}$ Device Is an Effective and Safe Non-Pharmacological Analgesic for Chronic Pain: A Meta-Analysis.. Advances in Therapy, 25, 644-657. http://dx.doi.org/10.1007/s12325-008-0073-3

[164] Gold, M.S., Blum, K., Oscar-Berman, M. and Braverman, E.R. (2014) Low Dopamine Function in Attention Deficit/ Hyperactivity Disorder: Should Genotyping Signify Early Diagnosis in Children? Postgraduate Medicine, 126, 153177. http://dx.doi.org/10.3810/pgm.2014.01.2735

[165] Blum, K., Femino, J., Teitlebaum, S., Giordano, J., Oscar-Berman, M. and Gold, M. (2013) Molecular Neurobiology of Addiction Recovery: The 12 Steps Program \& Fellowship. Springer Briefs in Neuroscience, Springer, New York, London. http://dx.doi.org/10.1007/978-1-4614-7230-8

\section{Abbreviations}

Substance Use Disorder (SUD): Dopamine D2 receptor gene (DRD2); Serotonin receptors (5-HTT2, 5-Htt2b and 5-Htt2c); Gaba receptor $\left(\mathrm{GABA}_{\mathrm{A}}\right)$; Monoamine-Oxidase (MAO); Catecholamine Methyl-Transferase (COMT); Geentic Addiction Risk Score $\left(\boldsymbol{G A R S} \boldsymbol{R}_{\boldsymbol{X}^{\mathrm{TM}}}\right)$; Neuroadaptagen Amino-Acid Therapy (KB220Z); England (UK); United States (US); Dopamine (DA); Dopamine D2 receptor (D2); nucleus accumbens (NAc); Gamma-Amino-Acid-Butyrate (GABA); National Institute on Alcohol Abuse and Alcoholism [NIAAA]; DA receptors (D1-D5); Attention-Deficit Hyperactivity Disorder (ADHD); Reward Deficiency Syndrome (RDS); monoamine oxidase B (MAO-B); MAOA gene (MAOCA-1); polymerase chain reaction (PCR); high activity homozygotes (genotype: $\mathrm{HH}$ ); low activity allele (genotype: $\mathrm{LL}$ ); central nervous system (CNS); Children of Alcoholics (COA); glutamate decarboxylase-2 (GAD2); Single Nucleotide Polymorphism (SNP); alcoholpreferring (P); non-preferring (NP); Herz (HZ); visual analog scale (VAS); Males (M); Females(F); estimated ES variance $\left(\mathrm{M}_{\mathrm{ES}} \mathrm{V}\right)$; alcohol expectancy (AE); drinking refusal self-efficacy (DRSE); against medical advice rate (AMA); Pre-enkephalin (PENK), Mu-opiate receptor (MOR); Driving Under the Influence(DUI); Percent (\%); Milligram (MG); Gram (GM); Addiction Severity Index (ASI); Addiction Medicine (ASAM). 
Scientific Research Publishing (SCIRP) is one of the largest Open Access journal publishers. It is currently publishing more than 200 open access, online, peer-reviewed journals covering a wide range of academic disciplines. SCIRP serves the worldwide academic communities and contributes to the progress and application of science with its publication.

Other selected journals from SCIRP are listed as below. Submit your manuscript to us via either submit@scirp.org or Online Submission Portal.
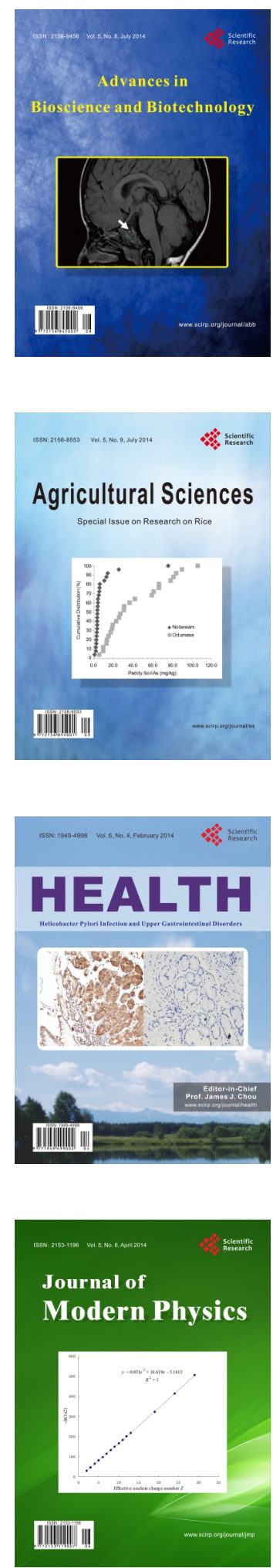
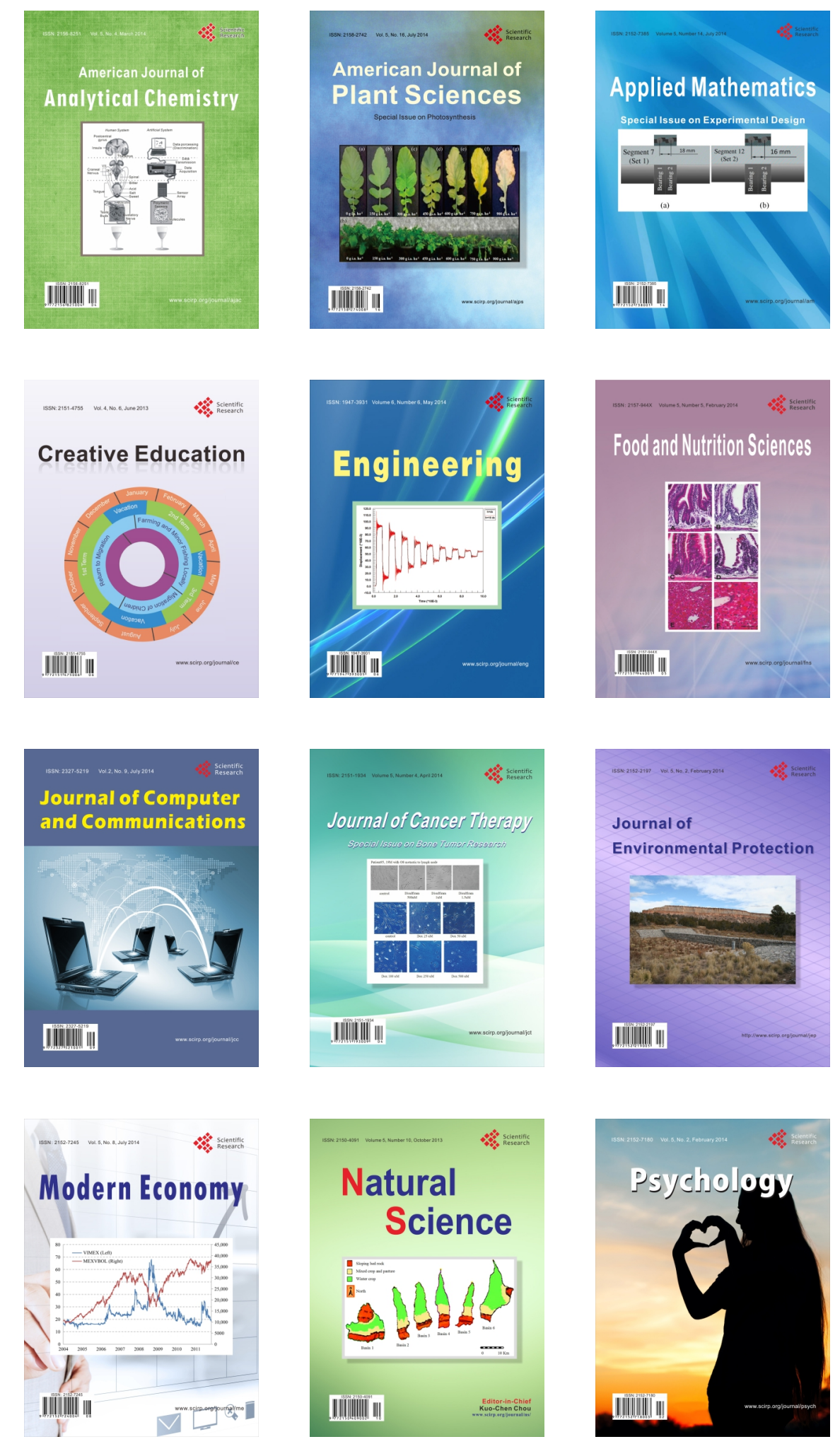